\title{
Phytoplankton of the Curonian Lagoon as a New Interesting Source for Bioactive Natural Products. Special Impact on Cyanobacterial Metabolites
}

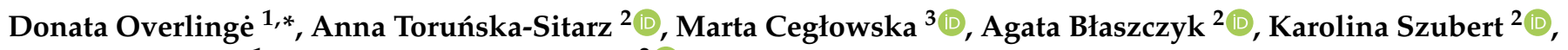 \\ Renata Pilkaityte ${ }^{1}$ and Hanna Mazur-Marzec ${ }^{2}$ (B) \\ 1 Marine Research Institute, Klaipeda University, University Avenue 17, 92295 Klaipeda, Lithuania; \\ renata.pilkaityte@apc.ku.lt \\ 2 Division of Marine Biotechnology, Faculty of Oceanography and Geography, University of Gdańsk, \\ Marszałka J. Piłsudskiego 46, PL-81378 Gdynia, Poland; anna.torunska@ug.edu.pl (A.T.-S.); \\ agata.blaszczyk@ug.edu.pl (A.B.); karolina.szubert@phdstud.ug.edu.pl (K.S.); \\ hanna.mazur-marzec@ug.edu.pl (H.M.-M.) \\ 3 Institute of Oceanology, Polish Academy of Sciences, Powstańców Warszawy 55, PL-81712 Sopot, Poland; \\ mceglowska@iopan.pl \\ * Correspondence: donata.overlinge@apc.ku.lt
}

\section{check for}

updates

Citation: Overlingè, D.

Toruńska-Sitarz, A.; Cegłowska, M.; Błaszczyk, A.; Szubert, K.; Pilkaitytè,

R.; Mazur-Marzec, H. Phytoplankton of the Curonian Lagoon as a New Interesting Source for Bioactive Natural Products. Special Impact on Cyanobacterial Metabolites. Biomolecules 2021, 11, 1139. https:// doi.org/10.3390/biom11081139

Academic Editor: Christophe Brunet

Received: 18 June 2021

Accepted: 29 July 2021

Published: 2 August 2021

Publisher's Note: MDPI stays neutral with regard to jurisdictional claims in published maps and institutional affiliations.

Copyright: (c) 2021 by the authors. Licensee MDPI, Basel, Switzerland. This article is an open access article distributed under the terms and conditions of the Creative Commons Attribution (CC BY) license (https:// creativecommons.org/licenses/by/ $4.0 /)$.

\begin{abstract}
The bioprospecting of marine and brackish water systems has increased during the last decades. In this respect, microalgae, including cyanobacteria, and their metabolites are one of the most widely explored resources. Most of the bioactive compounds are isolated from ex situ cultures of microorganisms; however, analysis of field samples could also supply valuable information about the metabolic and biotechnological potential of microalgae communities. In this work, the activity of phytoplankton samples from the Curonian Lagoon was studied. The samples were active against antibiotic resistant clinical and environmental bacterial strains as well as against serine proteases and T47D human breast adenocarcinoma cells. No significant effect was found on Daphnia magna. In addition, using LC-MS/MS, we documented the diversity of metabolites present in field samples. A list of 117 detected cyanopeptides was presented. Cyanopeptolins constituted the largest class of cyanopeptides. As complex bloom samples were analyzed, no link between the observed activity and a specific sample component can be established. However, the results of the study showed a biotechnological potential of natural products from the Curonian Lagoon.
\end{abstract}

Keywords: phytoplankton; cyanobacteria; antibacterial compounds; enzymatic activity; cytotoxicity; acute toxicity; Baltic Sea

\section{Introduction}

The brackish water Curonian Lagoon, located along the south-eastern part of the Baltic Sea, is one of the largest lagoons in Europe. As a highly eutrophic water body, it annually experiences massive blooms of microalgae [1-4]. The spring phytoplankton community is dominated by diatoms, mainly Stephanodiscus hantzschii, Diatoma tenuis, Aulacoseira islandica, Asterionella formosa [5,6]. During the summer-autumn seasons, cyanobacteria are the main phytoplankton component. Among them, Aphanizomenon spp., Planktothrix agardhii, Dolichospermum spp., Microcystis spp., Woronichinia compacta, Limnothrix redekei are dominant $[1,7,8]$. Cyanobacteria and eukaryotic microalgae, mainly diatoms and green algae, generate a high diversity of metabolites, with an important ecological function and/or potential of biotechnological application.

Previous research in the Curonian Lagoon has only focused on the ecotoxicological assessment of cyanobacterial scum and cyanobacterial toxins from the perspective of the ecosystem and public health [7,9-13]. To our knowledge, no published data on the biological activity of metabolites produced by cyanobacteria and eukaryotic microalgae 
occurring in this lagoon exist. In terms of cyanobacterial toxins, the presence of various microcystin (MC) analogues, anatoxin-a (ANTX-a) and nodularin (NOD) has been confirmed $[7,9,12,13]$. Reports on the detection of cyanopeptides in the Curonian Lagoon was also published $[10,13]$.

It is well documented that cyanobacteria are leaders among the natural sources of bioactive compounds. Most frequently, their cytotoxic effect has been described [14,15]. Like other microalgae groups (diatoms, green microalgae), cyanobacteria also show considerable antibacterial potential and can inhibit the growth of multidrug-resistant pathogens [16-18]. In addition, secondary metabolites produced by microalgae and cyanobacteria exhibit anti-inflammatory, antioxidant, anticoagulant, antiprotozoal and antiviral activities [19].

In general, the bioprospecting of marine and brackish water systems has highly increased during the last few decades. In this respect, microalgae and their metabolites are one of the most widely explored resources. Especially in areas such as pharmacy, aquaculture, bioremediation, bioenergy, biorefinery and biopigmentation [20,21]. Due to the urgent need for more effective and safer medicines for the treatment of cancer, metabolic disorders and infections caused by multidrug-resistant microorganisms, the search for new natural products for the pharmaceutical industry has been recently intensified [22-24].

To date, the potential for biotechnological application of more than 10,000 new compounds from these resources has been assessed [21,25]. Most of the bioactive compounds were isolated from ex situ cultures of microorganisms. However, in some cases, the biosynthesis of specific metabolites might not be triggered under laboratory conditions $[17,26]$. Some microalgae that live naturally in the aquatic environment show metabolic plasticity under stressed vs. non-stressed conditions. Abiotic and biotic stress can provide an extra advantage of triggering the synthesis of secondary metabolites [27]. However, the identification of their producer in field samples can present a challenge and the reproducibility of biological effects is rather unlikely. Therefore, in further studies isolated strains and their metabolites should be explored. On the other hand, the analysis of phytoplankton bloom samples supplies valuable information about the metabolic and biotechnological potential of the organisms living in the analyzed ecosystem [28].

The objectives of this study were: (1) to assess the biotechnological potential of phytoplankton from the Curonian Lagoon using enzymatic, antimicrobial, and cytotoxicity assays as well as acute toxicity assay; (2) to document the diversity of bioactive cyanometabolites from the Curonian Lagoon.

\section{Materials and Methods}

\subsection{Field Samples Collection}

The samples (Sample ID 1-9, Table 1) were collected from two stations (Nida and Juodkrante (Figure 1), depending on the highest surface accumulation of the phytoplankton) every second week from June until August in 2018. To collect higher biomass for activity screening, water samples were concentrated using $55 \mu \mathrm{m}$ Apstein plankton net and centrifuged at $3444 \times g, 8^{\circ} \mathrm{C}$ for $10 \mathrm{~min}$ (Centrifuge $5810 \mathrm{R}$, Eppendorf ${ }^{\circledR}$, Hamburg, Germany). Then, the samples were frozen and freeze-dried. Subsamples for phytoplankton analyzes, both concentrated and non-concentrated, were fixed with Lugol's iodine solution. 
Table 1. Testing steps and assays performed with extracts and fractions of the collected samples (N represents Nida site, J-Juodkrante site).

\begin{tabular}{|c|c|c|c|c|c|c|c|c|c|}
\hline \multicolumn{2}{|c|}{ Collected Samples } & \multicolumn{2}{|c|}{ 1st Testing Step } & \multicolumn{3}{|c|}{ 2nd Testing Step } & \multicolumn{3}{|c|}{ 3rd Testing Step } \\
\hline Sampling dates & Sample ID & Extract ID & Assay & \multicolumn{2}{|c|}{ ID $^{1}$ of the fractions tested } & Assay & \multicolumn{2}{|c|}{ ID $^{2}$ of the fractions tested } & Assay \\
\hline N2018.06.24 & 1 & I & & & - & - & & - & - \\
\hline N2018.06.28 & 2 & II & & & - & - & & - & - \\
\hline $\mathrm{J} 2018.07 .11$ & 3 & III & & & - & - & & - & - \\
\hline J2018.07.20 & 4 & IV & $\begin{array}{c}\text { acute } \\
\text { toxicity, } \\
\text { antibacterial, }\end{array}$ & I & IV-[10-100 $]^{3}$ & $\begin{array}{c}\text { antibacterial, } \\
\text { cytotoxicity }\end{array}$ & II & $\begin{array}{l}\text { IV-60-[20;40; } \\
60 ; 90 ; 100]^{3} ; \\
\text { IV-70-[20;40; } \\
60 ; 90 ; 100]^{3}\end{array}$ & cytotoxicity \\
\hline N2018.07.23 & 5 & $\mathrm{~V}$ & $\begin{array}{l}\text { enzyme } \\
\text { inhibition, }\end{array}$ & fractionation & V-[10-100 $]^{3}$ & antibacterial & fractionation & - & - \\
\hline N2018.08.03 & 6 & VI & cytotoxicity & & - & - & & - & - \\
\hline N2018.08.09 & 7 & VII & & & - & - & & - & - \\
\hline N2018.08.16 & 8 & VIII & & & VIII- $\underset{3}{10-100]}$ & $\begin{array}{l}\text { enzyme } \\
\text { inhibition }\end{array}$ & & - & - \\
\hline N2018.08.30 & 9 & IX & & & IX-[10-100 $]^{3}$ & & & - & - \\
\hline
\end{tabular}

1 _ sample ID indicates: extract number (I-IX); I fractionation, fraction number; ${ }^{2}$ — sample ID indicates: extract number; I fractionation, fraction number; II fractionation, fraction number; ${ }^{3}$-numbers in square brackets represent eluent from $10 \%$ to $100 \%$ methanol (for 2 nd Testing Step-every 10\% (10 fractions for each extract); for 3rd Testing Step-20\%, 40\%, 60\%, 90\% and 100\% methanol in MilliQ water); "-" - not tested.

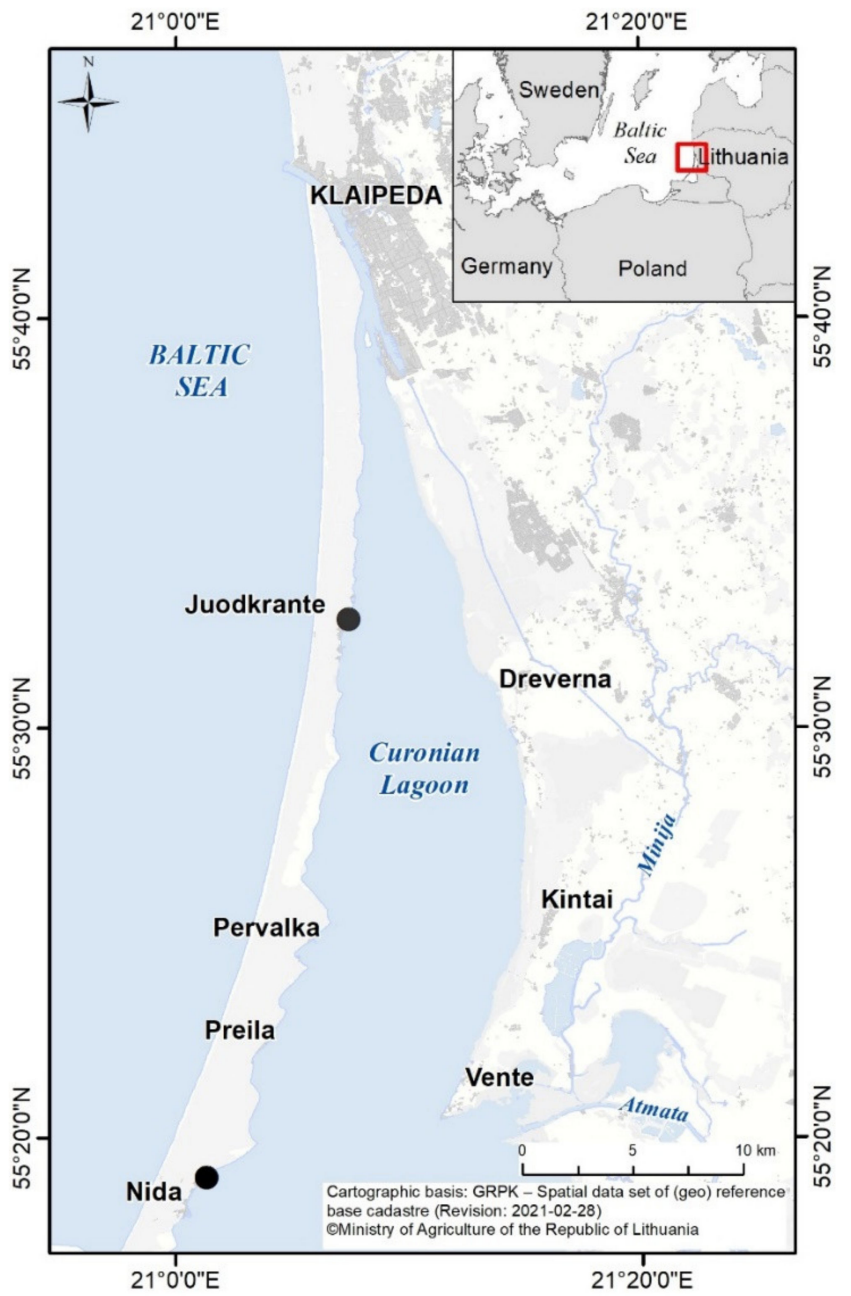

Figure 1. The study area and the locations (black circles) of the two sampling sites in the Curonian Lagoon (Nida and Juodkrante). 


\subsection{Phytoplankton Analysis}

The qualitative and quantitative analyses of the phytoplankton community composition were conducted using a LEICA DMI 3000 (Leica Microsystems CMS, Wetzlar, Germany) inverted microscope at magnifications of $\times 100$ and $\times 400$. The qualitative analysis of concentrated phytoplankton samples was carried out using Nunclon $10 \mathrm{~mL}$ 6-well chambers [28]. The quantitative phytoplankton analysis was performed according to the methodology described by Utermöhl [29]; the phytoplankton abundance and biomass was calculated according to the methodology described by HELCOM [30] and Olenina et al. [31]. Detailed description of the methods used for calculation of phytoplankton abundance and biomass can be found in the Supplementary Materials. Phytoplankton was identified to the lowest possible taxonomic level using guidelines described in the literature for the freshwater and brackish environments [32-35].

\subsection{Extraction and Fractionation of Phytoplankton Biomass}

Freeze-dried phytoplankton biomass was extracted with $75 \%$ methanol by vortexing for $15 \mathrm{~min}$ and centrifuged $\left(19,837 \times g, 4^{\circ} \mathrm{C}\right.$ for $20 \mathrm{~min}$ ) (Centrifuge $5810 \mathrm{R}$, Eppendorf ${ }^{\circledR}$, Hamburg, Germany). The supernatants were diluted with MilliQ water, to lower the concentration of methanol below $10 \%$. Then, the samples were partially purified by passing through preconditioned Waters Sep-Pak ${ }^{\circledR}$ Vac 20cc C18 cartridges (5 g) (Waters, Milford, MA, USA). The extracts were eluted by washing the cartridges with $90 \%$ methanol in MilliQ water. The collected extracts were then evaporated using a miVac QUATTRO centrifugal vacuum concentrator (SP Scientific, Ipswich, UK) to the dry residue and depending on the bioassay (antibacterial, enzyme inhibition, cytotoxicity, or acute toxicity) (see methodology below) prepared for the first testing step (1st t.s.) (Table 1).

Based on the bioactivity response obtained in the MTT, antibacterial and enzyme inhibition assays (1st t.s.), extracts IV, V, VIII and IX, were selected for further investigation (Table 1, second testing step (2nd t.s.)). The dried extracts were dissolved in 75\% methanol $(10 \mathrm{~mL})$ by vortexing for $10 \mathrm{~min}$ and diluted in MilliQ water to lower the methanol concentration $(<10 \%)$, centrifuged $\left(19,837 \times g, 4{ }^{\circ} \mathrm{C}\right.$ for $10 \mathrm{~min}$ ) (Centrifuge $5810 \mathrm{R}$, Eppendorf ${ }^{\circledR}$, Hamburg, Germany) and filtered through GF/A filters (Whatman International Ltd., Kent, UK). The supernatants were then loaded onto a preconditioned flash chromatography Biotage ${ }^{\circledR}$ SNAP KP-C18-HS (120 g) column (Biotage, Uppsala, Sweden). Fractionation was performed using Shimadzu HPLC system model LC-20AP (Shimadzu, Canby, OR, USA) equipped with a photodiode array detector (PDA). PDA operated in a range from 190 to $500 \mathrm{~nm}$ and during all chromatographic runs, the absorbance at 210 and $280 \mathrm{~nm}$ was recorded. Samples were loaded onto a preconditioned column at a flow rate of $12 \mathrm{~mL}$ $\mathrm{min}^{-1}$. After washing the resin with MilliQ water the sorbed substances were eluted with methanol: water mixture, gradually increasing the strength of the eluent (by $10 \%$ at each step) from $10 \%$ to $100 \%$ methanol. A volume of $12 \mathrm{~mL}$ was collected for each fraction. Based on the results of the MTT assay (2nd t.s.), fractions V-60 and V-70 were further separated (3rd t.s.)). The second (II) fractionation of V-60 and V-70 was performed manually using Waters Sep-Pak ${ }^{\circledR}$ Vac $(50 \mathrm{mg})$ (Waters, Milford, MA, USA). Sorbed metabolites were eluted with $20 \%, 40 \%, 60 \%, 90 \%$, and 100\% methanol in MilliQ water. The collected fractions (I and II fractionation) were evaporated as described above.

\subsection{Antibacterial Activity}

\subsubsection{Bacterial Strains}

Antibacterial activity was tested against 8 bacterial strains-Staphylococcus aureus CCNPB/1505, Pseudomonas aeruginosa CCNPB/MBL, Acinetobacter baumanii CCNPB/O, Enterococcus faecium 45, Aeromonas salmonicida 2013, Vibrio cholerae 2329, Vibrio diazotrophicus Cd1 and Klebsiella pneumoniae CCNPB/1404 (Table S1). Four clinical isolates (no. 1-4) were kindly provided by Kamila Korzekwa PhD, Medical Laboratories Center Dialab (Wrocław, Poland) and are now kept in the Culture Collection of Northern Poland at Division of Marine Biotechnology (CCNP), University of Gdańsk. Environmental isolates 
were obtained from Ewa Kotlarska PhD, Institute of Oceanology Polish Academy of Sciences (isolates no. 5-7 from IO PAN MB Strain Collection Institute of Oceanology, Polish Academy of Sciences, Molecular Biology Laboratory) and Aneta Łuczkiewicz PhD, Gdańsk University of Technology (isolate no. 8 from Department of Water and Wastewater Technology Strain Collection) [36-38].

\subsubsection{Antibacterial Assay}

Broth microdilution assay was performed according to the European Committee on Antimicrobial Susceptibility Testing (EUCAST) recommendations (http:/ / www.eucast.org, accessed on 18 January 2021). Before the experiments, the bacteria were grown overnight on Mueller Hinton (Sigma-Aldrich, Steinheim, Germany) agar at $36^{\circ} \mathrm{C}$. For the experiment, bacterial suspensions (prepared in Ringer's solution and equal to 0.5 of McFarland standard

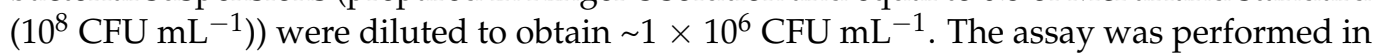
96-well sterile microplates (Eppendorf, Hamburg, Germany). The extracts and fractions were diluted in $2 \% \mathrm{v} / \mathrm{v}$ DMSO and tested in triplicates at concentrations of 500, 250, 100 and $10 \mu \mathrm{g} \mathrm{mL}{ }^{-1}$. The fractions were prepared using a two-fold serial microdilution method. The concentration of the fractions used in the experiment ranged from $1.95 \mu \mathrm{g} \mathrm{mL}^{-1}$ to $1000 \mu \mathrm{g} \mathrm{mL}{ }^{-1}$. The 96-well microplates were incubated overnight (Gram - for $16 \mathrm{~h}, \mathrm{Gram}+$ for $24 \mathrm{~h}$ ) at $36{ }^{\circ} \mathrm{C}$. The optical density (OP) of each well was measured at $620 \mathrm{~nm}$ using SpectraMax ${ }^{\circledR}$ i3 Platform (Molecular Devices, San Jose, CA, USA). The percentage of growth inhibition was calculated in comparison to the control (bacterial culture without the extract/fraction).

\subsection{Cytotoxicity Assay}

Cytotoxicity assay was performed on human breast adenocarcinoma cell line T47D (Merck KGaA, Darmstadt, Germany). The assay was performed based on the colorimetric MTT assay method described by Felczykowska [39]. T47D cells were plated at a concentration of $1 \times 10^{4}$ cells per well of 96-well plate containing RPMI1640 (Carl Roth GmbH \& Co. KG, Karlsruhe, Germany) medium supplemented with 10\% fetal bovine serum (Merck KGaA, Darmstadt, Germany) and penicillin-streptomycin solution (50 U and $0.05 \mathrm{mg}$ $\mathrm{mL}^{-1}$, respectively; Merck KGaA, Darmstadt, Germany) and allowed to attach overnight (24 h of incubation at $37^{\circ} \mathrm{C}$; in $\mathrm{CO}_{2}(5 \%)$ ). After the incubation, the medium was replaced with a fresh portion of extracts or fractions dissolved in 1\% v/v DMSO (Merck KGaA, Darmstadt, Germany) at final concentrations 200, 100, 50 and $25 \mu \mathrm{g} \mathrm{mL}^{-1}$. The test was performed in three replicates for all the tested extracts, fractions and control samples. Plates were incubated for $24 \mathrm{~h}\left(37^{\circ} \mathrm{C}\right)$. Then, $25 \mu \mathrm{L}$ of MTT solution $\left(4 \mathrm{mg} \mathrm{mL}{ }^{-1}\right)$ was added to each well. After $4 \mathrm{~h}$ of incubation, the medium was removed and $100 \mu \mathrm{L}$ of $100 \%$ DMSO was added to dissolve the formazan. The absorbance of the reaction mixtures was measured at $570 \mathrm{~nm}$ (with reference wavelength $660 \mathrm{~nm}$ ) using a microplate reader (Spectramax i3, Molecular Devices, San Jose, CA, USA). Cell survival was calculated as the ratio of the mean absorbance of the tested samples in comparison to the control (mean absorbance of the corresponding solvent) and expressed as a percentage.

\subsection{Enzyme Inhibition Assay}

Trypsin inhibition assay was performed according to the methodology described by Pluotno and Carmeli [40], chymotrypsin and thrombin assay followed the procedure by Ocampo Bennet [41]. The extracts and fractions were diluted in 1\% v/v DMSO at final concentrations of 45 and $4.5 \mu \mathrm{g} \mathrm{mL}^{-1}$. Standard inhibitors were used as a positive control and $1 \% \mathrm{v} / \mathrm{v}$ DMSO with the addition of buffer, as a negative control. The absorbance of the solutions was measured at $405 \mathrm{~nm}$ with the application of a microplate reader (Varioskan Flash Thermo Fisher Scientific OY, Finland).

The final concentrations of enzymes used for the assays were $0.1 \mathrm{mg} \mathrm{mL}^{-1}$ for trypsin and chymotrypsin and $0.5 \mathrm{mg} \mathrm{mL}^{-1}$ for thrombin. In the case of trypsin and chymotrypsin, the mixtures containing the sample $(10 \mu \mathrm{L})$ or inhibitor $(10 \mu \mathrm{L})$, enzyme $(10 \mu \mathrm{L})$ and 
buffer $(100 \mu \mathrm{L})$ were preincubated for $5 \mathrm{~min}$ at $37^{\circ} \mathrm{C}$. Then, the substrate solution $(100 \mu \mathrm{L})$ was added, and the mixture was incubated for 10 additional min at $37^{\circ} \mathrm{C}$. In the case of thrombin, the sample $(10 \mu \mathrm{L})$ or inhibitor $(10 \mu \mathrm{L})$, with the addition of enzyme $(10 \mu \mathrm{L})$ and buffer $(170 \mu \mathrm{L})$ were preincubated at $36{ }^{\circ} \mathrm{C}$ for $10 \mathrm{~min}$ after which $20 \mu \mathrm{L}$ of the substrate was added. The solution was incubated for another $10 \mathrm{~min}$ at $36{ }^{\circ} \mathrm{C}$. The percentage of enzymatic inhibition was calculated in comparison to the positive control.

\subsection{Acute Toxicity Assay}

The toxicity of phytoplankton extracts towards the juvenile freshwater cladoceran Daphnia magna was evaluated in $24-\mathrm{h}$ and 48 -h bioassays. The tests were performed according to the procedure described by the producer (MicroBioTests Inc., Gent, Belgium) protocol. The test organisms were prepared for the experiment by incubating their cryptobiotic forms in Standard Medium (SM). The extracts were dissolved in 1\% DMSO at final concentrations 10,5 and $2.5 \mu \mathrm{g} \mathrm{mL}{ }^{-1}$. Specimens of $D$. magna were exposed to $10 \mathrm{~mL}$ of the prepared extracts. The assay plates containing ephippia ( 5 in each well) were incubated at $20{ }^{\circ} \mathrm{C}, 6000$ lux. The assay was performed in triplicate. The test endpoint was the death of the organisms. The results were presented as the percentage of surviving organisms.

\subsection{Analysis of Cyanometabolites}

Analyses of cyanometabolites were done using Agilent HPLC system (Agilent Technologies, Waldboronn, Germany) coupled to a hybrid triple quadrupole/linear ion trap mass spectrometer QTRAP LC-MS/MS (QTRAP5500, Applied Biosystems, Sciex; Canada) according to the method described by Mazur-Marzec et al. [42]. Chromatographic separation was performed on a Zorbax Eclipse XDB-C18 column $(4.6 \mu \mathrm{m}, 150 \mathrm{~mm}, 5 \mu \mathrm{m}$; Agilent Technologies, Santa Clara, CA, USA). To determine the content of crude extracts and fractions, the information-dependent acquisition method (non-target analysis) was used. Total ion current spectra were used to determine the most intense ion peaks. Data were processed with Analyst QS (Version 1.5.1, Applied Biosystems/MDS Analytical Technologies, Concord, ON, Canada, 2008).

\subsection{Statistical Analysis}

Non-parametric multidimensional scaling (nMDS) based on the Jaccard similarity coefficient [43] of presence-absence data, was used to represent the similarities of phytoplankton communities among the different samples. Phytoplankton samples were divided into groups with group-average linking [44]. One-way ANOSIM tests were used to determine the significances of the degree of separation among the nMDS groups. The stress values of the two MDS plots were determined, which is considered to adequately represent the similarity between the samples in nMDS plots. A stress value of $<0.2$ indicates an accurate representation of similarity rankings. nMDS and ANOSIM analyses were conducted using Primer v6 software. All biological experiments were carried out in triplicate, the data presented in this paper is expressed as a mean. The reliability of results was verified through the calculation of standard deviation.

\section{Results}

\subsection{Phytoplankton Community}

In total, 178 species were observed: 68 members of Chlorophyta, 35 of Bacillariophyta, 52 of Cyanophyta, 7 of Cryptophyta, 8 of Dinophyta, 3 of Euglenophyta, 2 of Chrysophyta and 1 of Haptophyta (Table S8). The phytoplankton species composition in the concentrated and non-concentrated samples did not differ. Single phytoplankton cell sizes varied from 0.4 to $700 \mu \mathrm{m}$, some were chain or colony-forming species.

Phytoplankton biomass and dominating phytoplankton groups differed among the samples (Figure 2, Table S8). Bacillariophyta accounted for the highest biomass in the majority of the samples (Figure 2a,b). The highest total biomass of the Bacillariophyta was measured in Samples 5, 6 and 7 (67-87\% of the total phytoplankton biomass (TPB)), 
the lowest was in Sample 2 (12\% of the TPB). Amongst the diatoms, Actinocyclus normanii accounted for the highest contribution of the TPB (30-70\% from the TPB), except Sample 2 (4\% from the TPB) (Table S8). Chlorophyta dominated only in Sample 2 (61\% of the TPB) (Figure $2 \mathrm{a}, \mathrm{b}$ ). Other phytoplankton groups did not exceed the $5 \%$ threshold of the TPB.
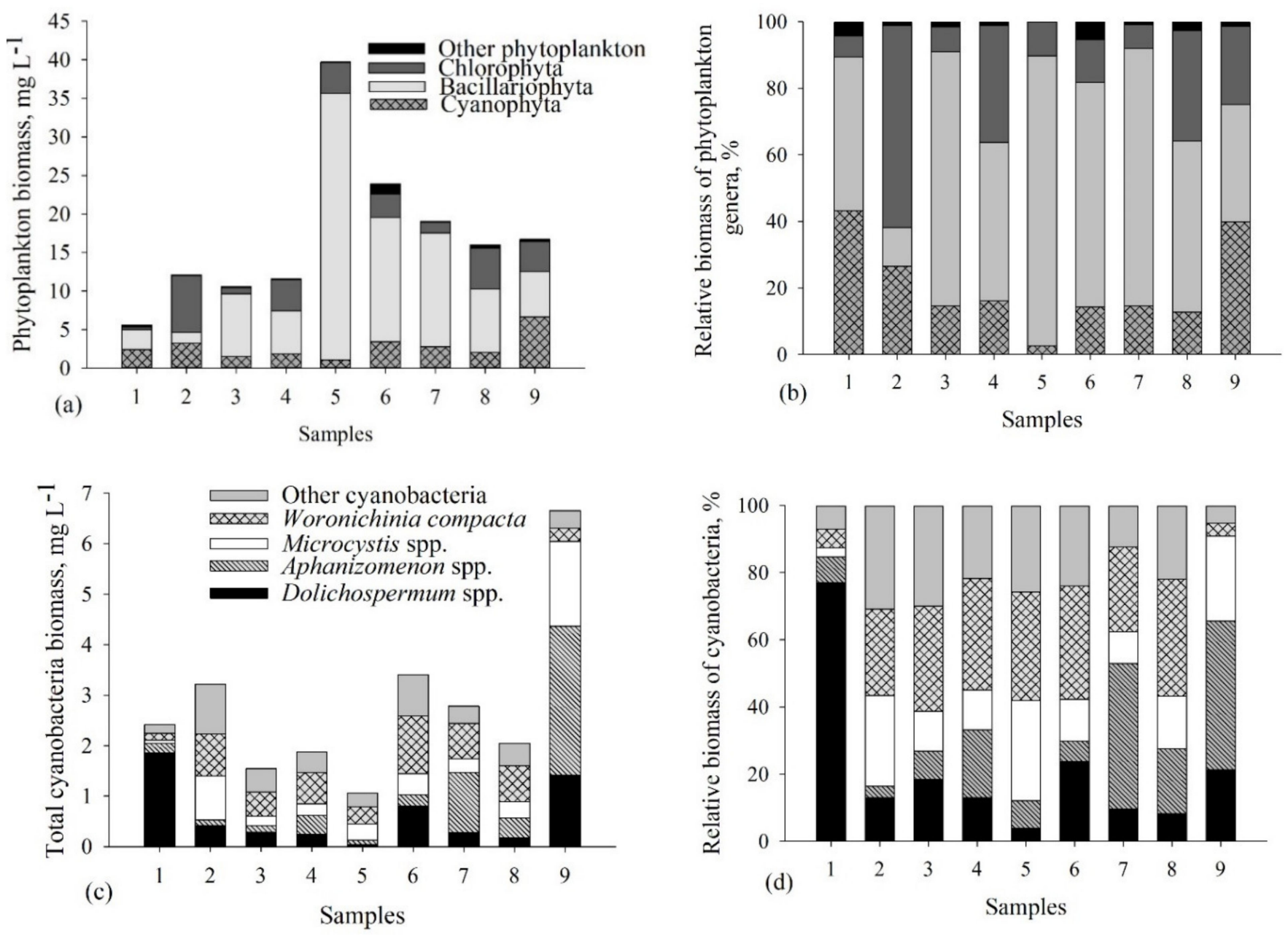

Figure 2. Structure, biomass $\left(\mathrm{mg} \mathrm{L}^{-1}\right)$ and relative biomass of phytoplankton $(\mathbf{a}, \mathbf{b})$ and cyanobacteria $(\mathbf{c}, \mathbf{d})$ community in the collected samples.

The highest contribution of cyanobacteria biomass was measured in Samples 1, 2 and 9 (27-43\% of the TPB), the lowest was in Sample 5 (3\% of the TPB) (Figure 2c,d, Table S8). Dolichospermum spp., Aphanizomenon spp., Microcystis spp. and Woronichinia compacta belonged to the dominant cyanobacterial genera (Figure $2 \mathrm{c}, \mathrm{d}$ ). An evident contribution of Dolichospermum flosaquae was observed only in Sample 1 (47\% of the total cyanobacterial biomass (TCB)), while in other samples this species accounted for less than $7 \%$ of the TCB (Table S8). In other samples, different species of Dolichospermum were also present (D. crassum, D. planctonicum, D. lemmermanii) and accounted for not more than $11 \%$ of the TCB. In comparison, Microcystis genus, M. wesenbergii and M. flosaquae, had a higher contribution to the biomass of Samples 2,5 and $9(\sim 10 \%$ of the TCB). The highest contribution of Aphanizomenon flosaquae was observed in Samples 7 and 9. W. compacta predominated in almost all samples (Samples 2-8) and accounted for 25-35\% of the TCB (Figure 2c,d, Table S8).

In order to highlight the importance of different phytoplankton communities leading to the potentially different bioactivity results (Tables 2 and 3, see results below), nMDS analysis of similarity was performed for each of the dominating phytoplankton communities (Bacillariophyta, Chlorophyta and Cyanophyta) separately (Figure S1). According 
to the obtained results based on Bacillariophyta and Chlorophyta, six samples out of nine did not differ in species composition and were grouped into one cluster (Group A) (Global $\mathrm{R}-1, p<0.01$ ) (Figure S1a,b). Despite the similarity of species composition in Group A, samples showed different bioactivity results in antibacterial, enzymatic, cytotoxic and acute toxicity bioassays (Tables 2 and 3). Considering the Cyanophyta community, nMDS analysis showed that the species composition was highly different among the samples (Global R $-0.765, p<0.01$ ) (Figure S1c) and indicated that the diversity of cyanobacteria influenced the recorded activity.

Table 2. Antibacterial activity of extracts obtained from the Curonian Lagoon phytoplankton. Results are expressed as a percentage of bacterial culture OD value compared to untreated control (100\% growth). Different colors highlight the differences in OD values of bacterial cultures (the color code is explained below the table).

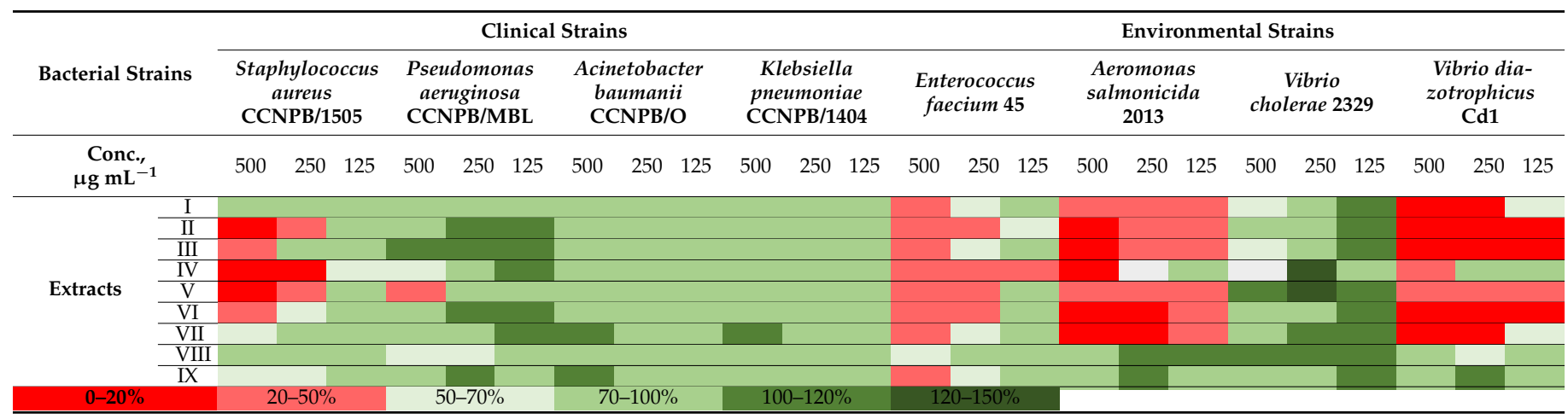

Table 3. Enzyme inhibition, cytotoxicity activity, and acute toxicity of phytoplankton extracts. Results are expressed as a percentage value of enzyme inhibition, cell viability (cytotoxicity assay) and cladocerans viability (acute toxicity assay), compared to untreated control. Different colors highlight the differences in values (the color code is explained below the table).

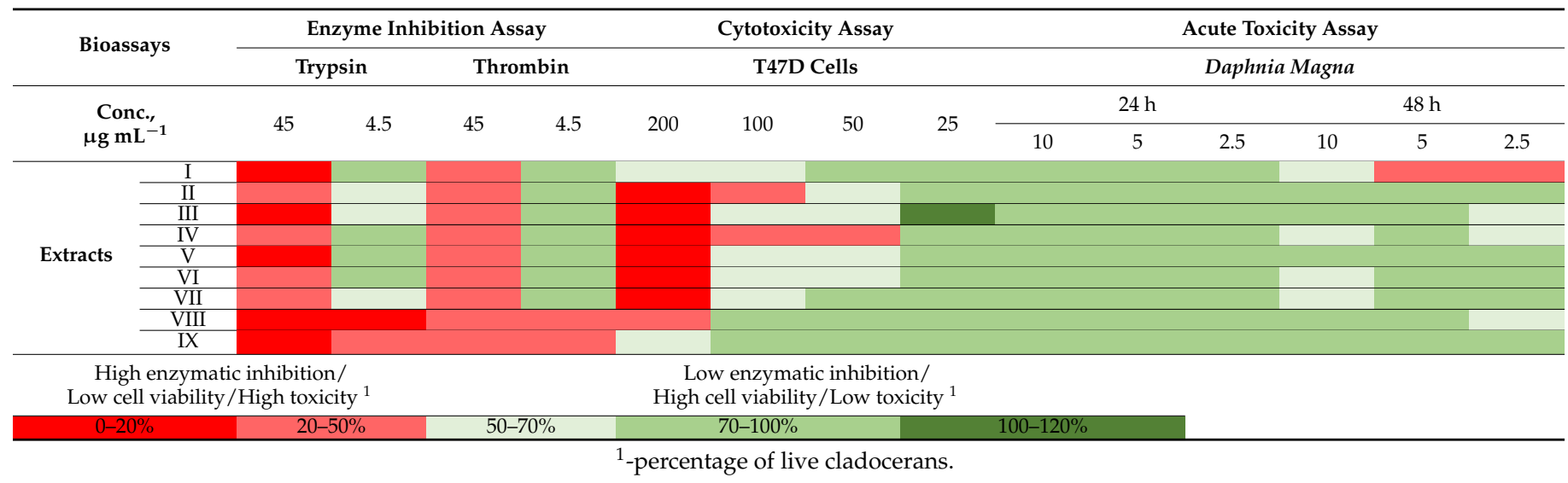

\subsection{Bioactivity Screening of the Phytoplankton Extracts}

To evaluate the biological activity of the extracts obtained from the collected phytoplankton, four different assays were applied (Tables 2 and 3, Tables S3 and S4). Considering the antibacterial assay, at least 50\% growth inhibition of the clinical strains (compared to the control) was obtained for the extracts II-VI (Table 2 and Table S3). In the case of S. aureus, extract IV, at $250 \mu \mathrm{g} \mathrm{mL}^{-1}$, reduced bacterial growth to less than $20 \%$ as compared to the control. Extract V, at 250 and $500 \mu \mathrm{g} \mathrm{mL}^{-1}$, inhibited two clinical strains, S. aureus and P. aeruginosa by more than $70 \%$ and $50 \%$, respectively. The growth of the environmental strains was inhibited by all tested extracts, except for extract VIII. V. diazotrophicus and A. salmonicida were found to be most sensitive to phytoplankton extracts I - VII. None of the extracts reduced the growth of $V$. cholerae and even slight growth stimulation was observed for the extracts IV and V. Extract IX only inhibited the growth of E. faecium 
45 (by 51\%). Irrespective of the strain used in the tests, extract VIII did not show any antibacterial activity.

In the enzymatic assay, all tested extracts inhibited trypsin and thrombin at the highest concentration ( $45 \mu \mathrm{g} \mathrm{mL}^{-1}$ ) (Table 3 and Table S4). The strongest effect was exhibited by extracts VIII and IX, which inhibited trypsin and thrombin even at the lowest concentration applied in the assay $\left(4.5 \mu \mathrm{g} \mathrm{mL}^{-1} ;>50 \%\right)$.

Considering the cytotoxicity assay, extracts II-VII decreased T47D cancer cells viability by more than $80 \%$ when applied at the highest concentration $\left(200 \mu \mathrm{g} \mathrm{mL}{ }^{-1}\right)$. At $50 \mu \mathrm{g} \mathrm{mL}^{-1}$, extract IV was most active (Table 3 and Table S4).

In the acute toxicity assay, after 24-h exposure, the extracts did not decrease the survivorship of D. magna (Table 3 and Table S4). Only the 48-h assay revealed a toxic effect of the samples. The dilutions of the extract I decreased the survivorship of cladocerans by approximately $52 \%$ (applied at $2.5 \mu \mathrm{g} \mathrm{mL}^{-1}$ ) and $58 \%$ (applied at $5 \mu \mathrm{g} \mathrm{mL}^{-1}$ ), in comparison with untreated organisms. Other extracts had a lower toxicity effect on $D$. magna; in the tests, $60-90 \%$ of the organisms survived.

\subsection{Bioactivity Screening of Fractions}

The extracts with the highest activity revealed in the assays were chosen for further fractionation and analyses. Extracts IV and V were chosen for antibacterial assays, extract IV for cytotoxicity assays and extracts VIII and IX for enzymatic assays (Table 4). As the effects of the samples on D. magna were rather weak and did not exceed $40 \%$ of the control, further tests on this organism were not performed.

Table 4. Antibacterial and cytotoxicity activities, and enzyme inhibition of fractions obtained after further separation of the extracts IV, V, VIII and IX.

\begin{tabular}{|c|c|c|c|c|c|c|c|c|c|c|c|c|c|c|c|c|c|c|c|c|}
\hline \multicolumn{21}{|c|}{ Antibacterial Assay } \\
\hline Extracts & \multicolumn{10}{|c|}{ IV } & \multicolumn{10}{|c|}{$\mathrm{V}$} \\
\hline Fractions $^{1}$ & 10 & 20 & 30 & 40 & 50 & 60 & 70 & 80 & 90 & 100 & 10 & 20 & 30 & 40 & 50 & 60 & 70 & 80 & 90 & 100 \\
\hline $\begin{array}{c}\text { Staphylococcus aureus } \\
\text { CCNPB/1505 }\end{array}$ & & - & - & - & - & - & + & ++ & + & + & - & - & - & - & - & - & + & + & ++ & + \\
\hline $\begin{array}{c}\text { Pseudomonas aeuruginosa } \\
\text { CCNPB/MBL }\end{array}$ & & - & - & - & - & - & - & - & - & - & - & - & - & - & - & - & - & - & - & - \\
\hline Enterococcus faecium 45 & & - & - & - & - & - & - & - & - & - & - & - & - & - & - & - & - & - & - & - \\
\hline Vibrio cholerae 2329 & & - & - & - & - & - & ++ & ++ & - & ++ & - & - & - & - & - & - & - & + & ++ & + \\
\hline $\begin{array}{l}\text { Aeromonas salmonicida } \\
2013\end{array}$ & & - & + & + & + & ++ & ++ & ++ & ++ & + & + & + & + & ++ & + & + & + & + & + & ++ \\
\hline Vibrio diazotrophicus $\mathrm{Cd} 1$ & & + & + & + & ++ & + & + & - & + & + & + & ++ & + & + & + & + & + & + & + & + \\
\hline \multicolumn{21}{|c|}{ Cytotoxicity Assay } \\
\hline Extracts & \multicolumn{20}{|c|}{ IV } \\
\hline Fractions $^{1}$ & 10 & 20 & 30 & 40 & 50 & 60 & 70 & 80 & 90 & 100 & & & & & & & & & & \\
\hline T47D & \multicolumn{2}{|c|}{-} & - & - & - & ++ & ++ & - & - & - & & & & & & & & & & \\
\hline Fractions (3rd testing & & & IV-50 & & \multicolumn{6}{|c|}{ IV-60 } & \multicolumn{5}{|c|}{ IV-70 } & & & & & \\
\hline step) & 20 & 40 & 60 & 90 & 100 & 20 & 40 & 60 & 90 & 100 & 20 & 40 & 60 & 90 & 100 & & & & & \\
\hline T47D & - & - & - & - & - & - & - & - & - & - & - & - & - & - & - & & & & & \\
\hline
\end{tabular}

Enzyme Inhibition Assay

\begin{tabular}{|c|c|c|c|c|c|c|c|c|c|c|c|c|c|c|c|c|c|c|c|c|}
\hline \multirow{2}{*}{$\begin{array}{c}\text { Extracts } \\
\text { Fractions }\end{array}$} & \multicolumn{10}{|c|}{ VIII } & \multicolumn{10}{|c|}{ IX } \\
\hline & 10 & 20 & 30 & 40 & 50 & 60 & 70 & 80 & 90 & 100 & 10 & 20 & 30 & 40 & 50 & 60 & 70 & 80 & 90 & 100 \\
\hline Trypsin & - & - & - & + & + & + & ++ & ++ & + & + & - & - & + & ++ & + & + & + & ++ & + & + \\
\hline Chymotrypsin & - & - & - & - & + & + & ++ & + & + & + & - & - & - & + & + & + & + & + & + & + \\
\hline Thrombin & - & - & - & + & + & + & + & + & + & - & - & - & - & + & ++ & + & + & + & - & - \\
\hline
\end{tabular}

1 -names of fractions (10-100; concentration of $\mathrm{MeOH}$ in water (10-100\%) used to elute the fractions); "++" indicates bacterial growth/enzymatic/cell viability inhibition by more than $80 \%$; "+" inhibition in the range $50-80 \%$; "-" inhibition lower than $50 \%$. Markings have been applied based on the activity obtained from the lowest tested concentration.

Fractions obtained from extracts IV and V inhibited the growth of four bacterial strains out of six applied in the antibacterial assays (Table 4 and Table S5). The fractions eluted with the solution containing the highest content of organic solvent (i.e., methanol) (IV-70 - 
100, V-70 - 100) were highly active against the tested strains, mainly S. aureus CCNPB/1505 (bacterial growth reduced to less than $20 \%$ of control) and $V$. cholerae 2329 (reduced to less than 10\%). The growth of A. salmonicida 2013 and $V$. diazotrophicus Cd1 was inhibited by almost all tested fractions (bacterial growth reduced to less than $50 \%$ of the control).

In the cytotoxicity assays, the viability of T45D cancer cells was affected by fractions IV60 and IV-70 (Table 4 and Table S7). The most potent activity was observed for the fraction IV-70, which decreased cell viability to $47 \%$ of the control at the lowest concentration used in the assay $\left(25 \mu \mathrm{g} \mathrm{mL}^{-1}\right)$. This fraction was used for the third testing step and the effect was observed only for the subfraction IV-70-90 (cell viability reduced to $22 \%$ at $\left.200 \mu \mathrm{g} \mathrm{mL}^{-1}\right)$.

In enzyme inhibition assays, fractions 40-100 obtained from the extracts VIII and IX showed inhibitory activity against tested enzymes (Table 4 and Table S6). In the case of trypsin, chymotrypsin and thrombin, the highest inhibitory activity was obtained for fractions 40, 70 and 80 (more than $80 \%$ applied at $4.5 \mu \mathrm{g} \mathrm{mL}{ }^{-1}$ ), fraction 70 (more than $60 \%$ applied at $4.5 \mu \mathrm{g} \mathrm{mL}{ }^{-1}$ ) and fraction 50 (more than $60 \%$ applied at $4.5 \mu \mathrm{g} \mathrm{mL}^{-1}$ ), respectively.

\subsection{Analysis of Cyanopeptides}

In bioactive fractions obtained from extracts IV, V, VIII and IX, 117 cyanopeptides were detected (Table S2). Although in many cases only partial structure identification was possible, due to the presence of several diagnostic ions in the fragmentation spectra (Figures 3-7, Figures S3-S12), the compounds could be assigned to one of the five cyanopeptide classes: the most numerous cyanopeptolins (CPs; 53 variants), microcystins (MCs; 19 variants), microginins (MGs; 18 variants), anabaenopeptins (APs; 14 variants) and aeruginosins (AERs; 13 variants).

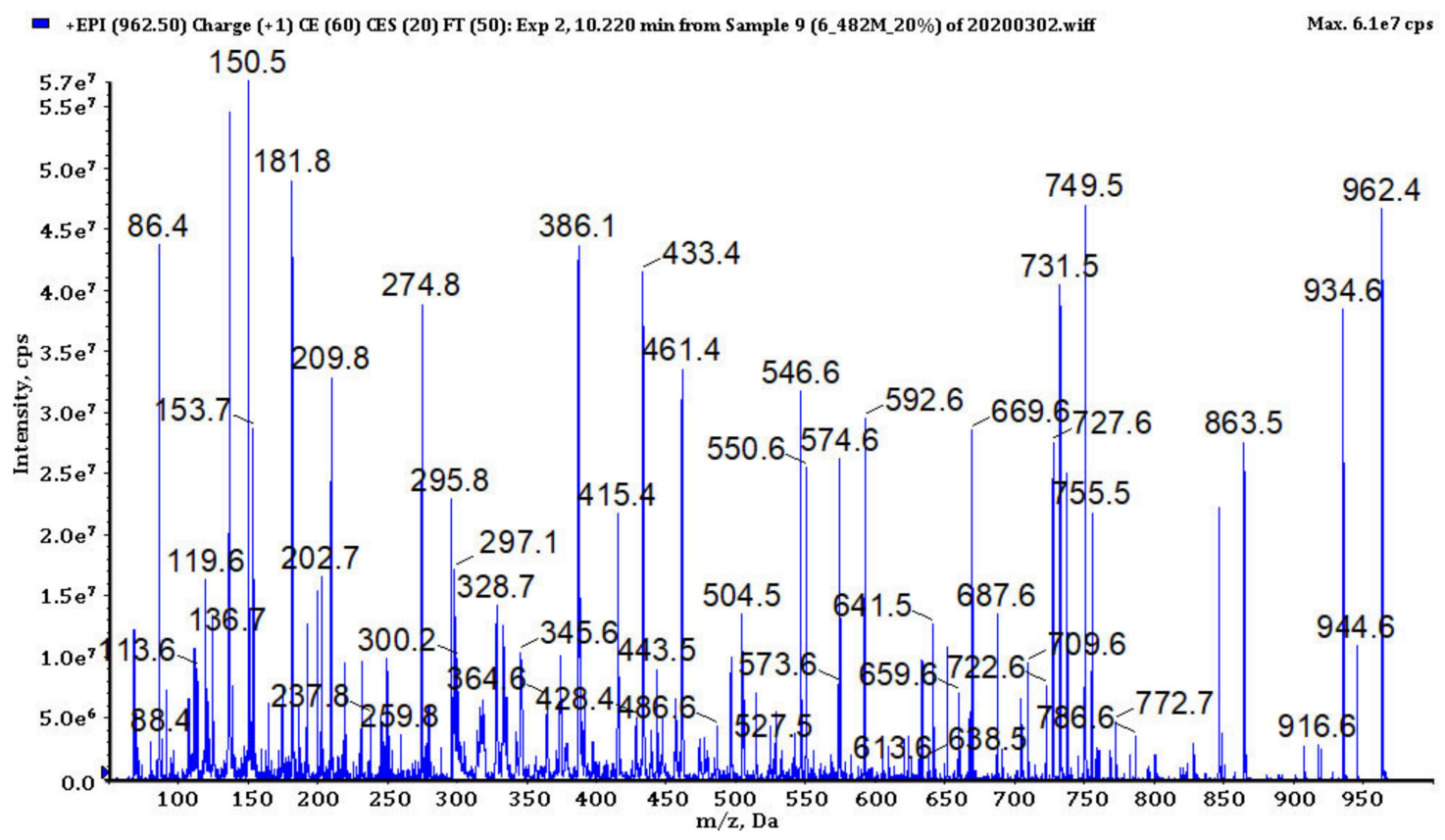

Figure 3. The enhanced product ion mass spectrum of cyanopeptoline CP979 with the suggested structure HA + Asp $\left[\mathrm{Thr}^{1}+\mathrm{Tyr}^{2}+\mathrm{Ahp}^{3}+\mathrm{Ile}^{4}+\mathrm{MeTyr}^{5}+\mathrm{Val}^{6}\right]$ and the following fragment ions: $m / z 962\left[\mathrm{M}+\mathrm{H}-\mathrm{H}_{2} \mathrm{O}\right]^{+}, 944[\mathrm{M}+\mathrm{H}-$ $\left.2 \mathrm{H}_{2} \mathrm{O}\right]^{+}, 934\left[\mathrm{M}+\mathrm{H}-\mathrm{H}_{2} \mathrm{O}-\mathrm{CO}^{+}, 916\left[\mathrm{M}+\mathrm{H}-2 \mathrm{H}_{2} \mathrm{O}-\mathrm{CO}\right]^{+}, 863\left[\mathrm{M}+\mathrm{H}-\mathrm{H}_{2} \mathrm{O}-\mathrm{HA}\right]^{+}, 749\left[\mathrm{M}+\mathrm{H}-\mathrm{H}_{2} \mathrm{O}-(\mathrm{HA}\right.\right.$ + Asp $)]^{+}, 731\left[\mathrm{M}+\mathrm{H}-2 \mathrm{H}_{2} \mathrm{O}-(\mathrm{HA}+\mathrm{Asp})\right]^{+}, 650\left[\mathrm{M}+\mathrm{H}-\mathrm{H}_{2} \mathrm{O}-(\mathrm{HA}+\mathrm{Asp})-\mathrm{Val}\right]^{+}, 461[\mathrm{HA}+\mathrm{Asp}+\mathrm{Thr}+\mathrm{Tyr}+$ $\left.\mathrm{H}-\mathrm{H}_{2} \mathrm{O}\right]^{+}, 386\left[\mathrm{Ahp}+\mathrm{Ile}+\mathrm{MeTyr}+\mathrm{H}-\mathrm{H}_{2} \mathrm{O}\right]^{+}, 297\left[\mathrm{Asp}+\mathrm{Thr}+\mathrm{Val}+\mathrm{H}-\mathrm{H}_{2} \mathrm{O}\right]^{+}, 209\left[\mathrm{Ahp}+\mathrm{Ile}+\mathrm{H}-\mathrm{H}_{2} \mathrm{O}\right]^{+}, 181$ $\left[\mathrm{Ahp}+\mathrm{Ile}+\mathrm{H}-\mathrm{H}_{2} \mathrm{O}-\mathrm{CO}\right]^{+}, 150$ MeTyr immonium, 136 Tyr immonium, 86 Ile immonium (HA - hexanoic acid, Ahp 3-amino-6-hydroxy-2-piperidone). 


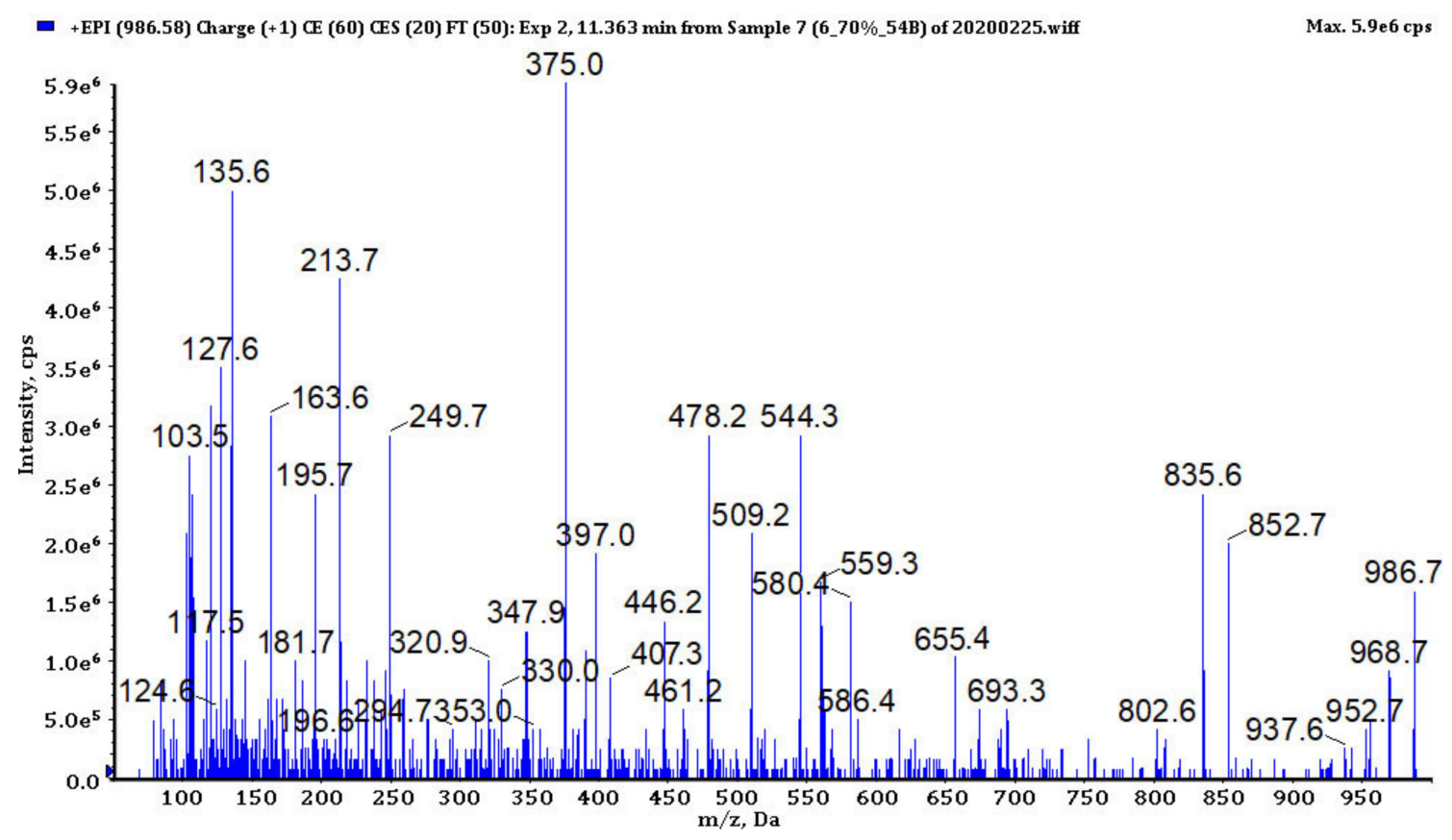

Figure 4. The enhanced product ion mass spectrum of microcystin MC-LF with the following fragment ions: $m / z 986[\mathrm{M}+$ $\mathrm{H}]^{+}, 968\left[\mathrm{M}+\mathrm{H}-\mathrm{H}_{2} \mathrm{O}\right]^{+}, 802[\mathrm{MeAsp}+\mathrm{Phe}+\mathrm{Adda}+\mathrm{Glu}+\mathrm{MeDha}+\mathrm{H}]^{+}, 655\left[\mathrm{M}+\mathrm{H}-\mathrm{Adda}-\mathrm{H}_{2} \mathrm{O}\right]^{+}, 580[$ Adda $+\mathrm{Glu}$ $\left.+\mathrm{MeDha}+\mathrm{Ala}+\mathrm{H}-\mathrm{NH}_{3}\right]^{+}, 559\left[\mathrm{C}_{11} \mathrm{H}_{14} \mathrm{O}+\mathrm{Glu}+\mathrm{MeDha}+\mathrm{Ala}+\mathrm{Leu}+\mathrm{H}\right]^{+}, 544[\mathrm{MeDha}+\mathrm{Ala}+\mathrm{Leu}+\mathrm{MeAsp}+\mathrm{Phe}+$ $\mathrm{H}]^{+}, 509\left[\text { Adda }+\mathrm{Glu}+\mathrm{MeDha}+\mathrm{H}-\mathrm{NH}_{3}\right]^{+}, 461[\mathrm{Ala}+\mathrm{Leu}+\mathrm{MeAsp}+\mathrm{Phe}+\mathrm{H}]^{+}, 446\left[\mathrm{C}_{11} \mathrm{H}_{14} \mathrm{O}+\mathrm{Glu}+\mathrm{MeDha}+\mathrm{Ala}+\right.$ $\mathrm{H}]^{+}, 407\left[\mathrm{Leu}+\mathrm{MeAsp}+\mathrm{Phe}+\mathrm{NH}_{4}\right]^{+}, 397[\mathrm{Glu}+\mathrm{MeDha}+\mathrm{Ala}+\mathrm{Leu}+\mathrm{H}]^{+}, 375\left[\mathrm{C}_{11} \mathrm{H}_{14} \mathrm{O}+\mathrm{Glu}+\mathrm{MeDha}+\mathrm{H}\right]^{+}, 213$ $[\mathrm{Glu}+\mathrm{MeDha}+\mathrm{H}]^{+}, 127\left[\mathrm{MeDha}+\mathrm{Ala}+\mathrm{H}-\mathrm{CO}^{+}, 120\right.$ Phe immonium (Adda - (3-amino-9-methoxy-2,6,8-trimethyl-10phenyldeca-4,6-dienoic acid) MeDha-methyldehydroalanine).

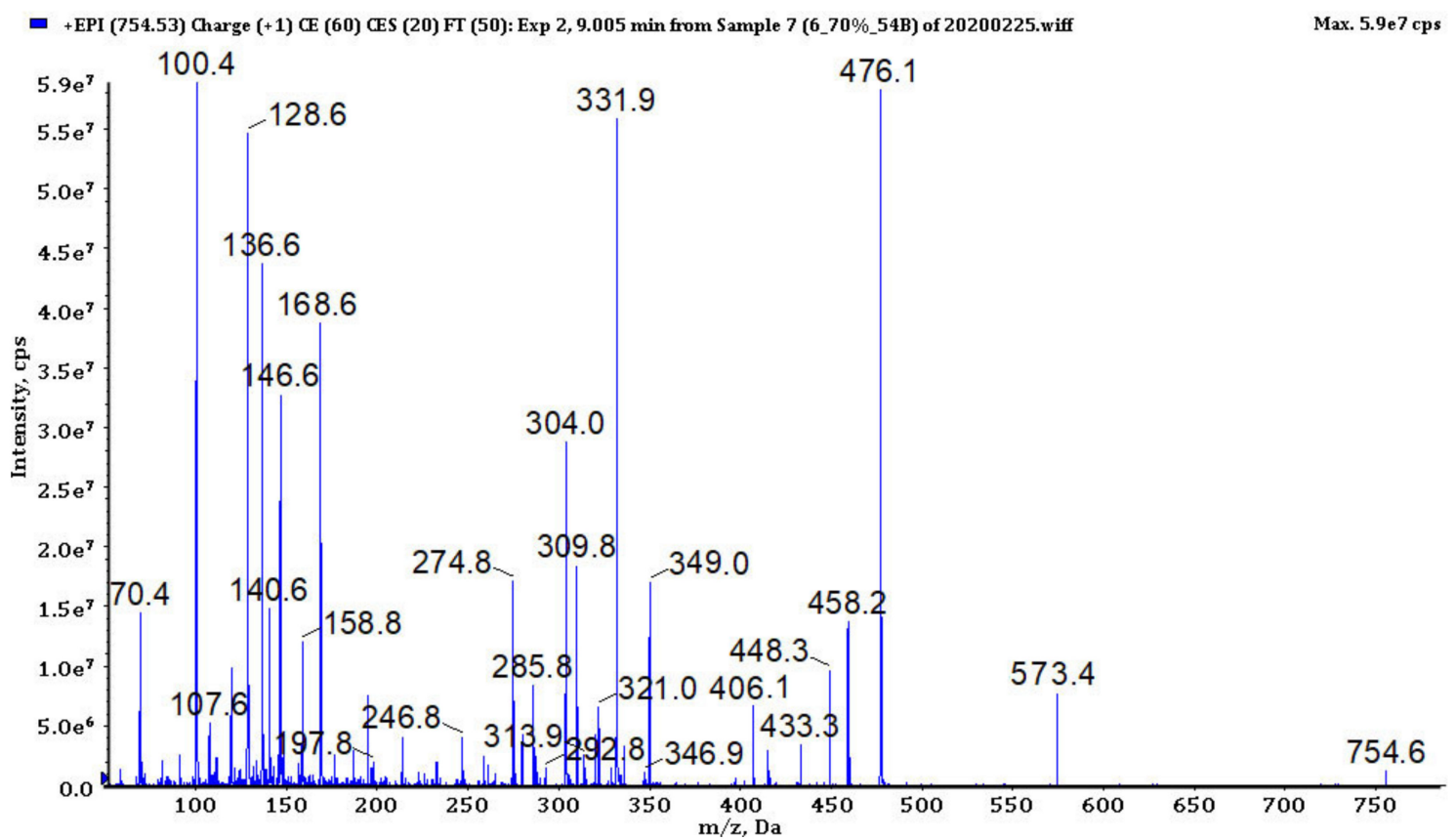

Figure 5. The enhanced product ion mass spectrum of microginin MG753 with the suggested structure Ahda + Tyr + MeIle/MeLeu + Pro + Tyr and the following fragment ions: $m / z 754[\mathrm{M}+\mathrm{H}]^{+}, 573[\mathrm{M}+\mathrm{H}-\mathrm{Tyr}]^{+}, 476[\mathrm{M}+\mathrm{H}-(\mathrm{Tyr}+$ Pro $)]^{+}, 458\left[\mathrm{M}+\mathrm{H}-(\mathrm{Tyr}+\text { Pro })-\mathrm{H}_{2} \mathrm{O}\right]^{+}, 448[\mathrm{M}+\mathrm{H}-(\mathrm{Tyr}+\mathrm{Pro})-\mathrm{CO}]^{+}, 406[\mathrm{MeLeu}+\text { Pro }+ \text { Tyr }+\mathrm{H}]^{+}, 349[\mathrm{M}+\mathrm{H}-$ $($ Tyr + Pro + MeLeu $)]^{+}, 331\left[\mathrm{M}+\mathrm{H}-(\mathrm{Tyr}+\mathrm{Pro}+\mathrm{MeLeu})-\mathrm{H}_{2} \mathrm{O}\right]^{+}, 321[\mathrm{M}+\mathrm{H}-(\mathrm{Tyr}+\text { Pro }+ \text { MeLeu })-\mathrm{CO}]^{+}, 279[\mathrm{Pro}+$ $\mathrm{Tyr}+\mathrm{H}]^{+}, 168\left[\mathrm{Ahda}-\mathrm{H}_{2} \mathrm{O}\right]^{+}, 158\left[\mathrm{Ahda}-\mathrm{CO}^{+}, 136 \mathrm{Tyr}\right.$ immonium, 128 Ahda fragment, 100 MeLeu immonium, 70 Pro immonium (Ahda - 3-amino-2-hydroxy-decanoic acid). 


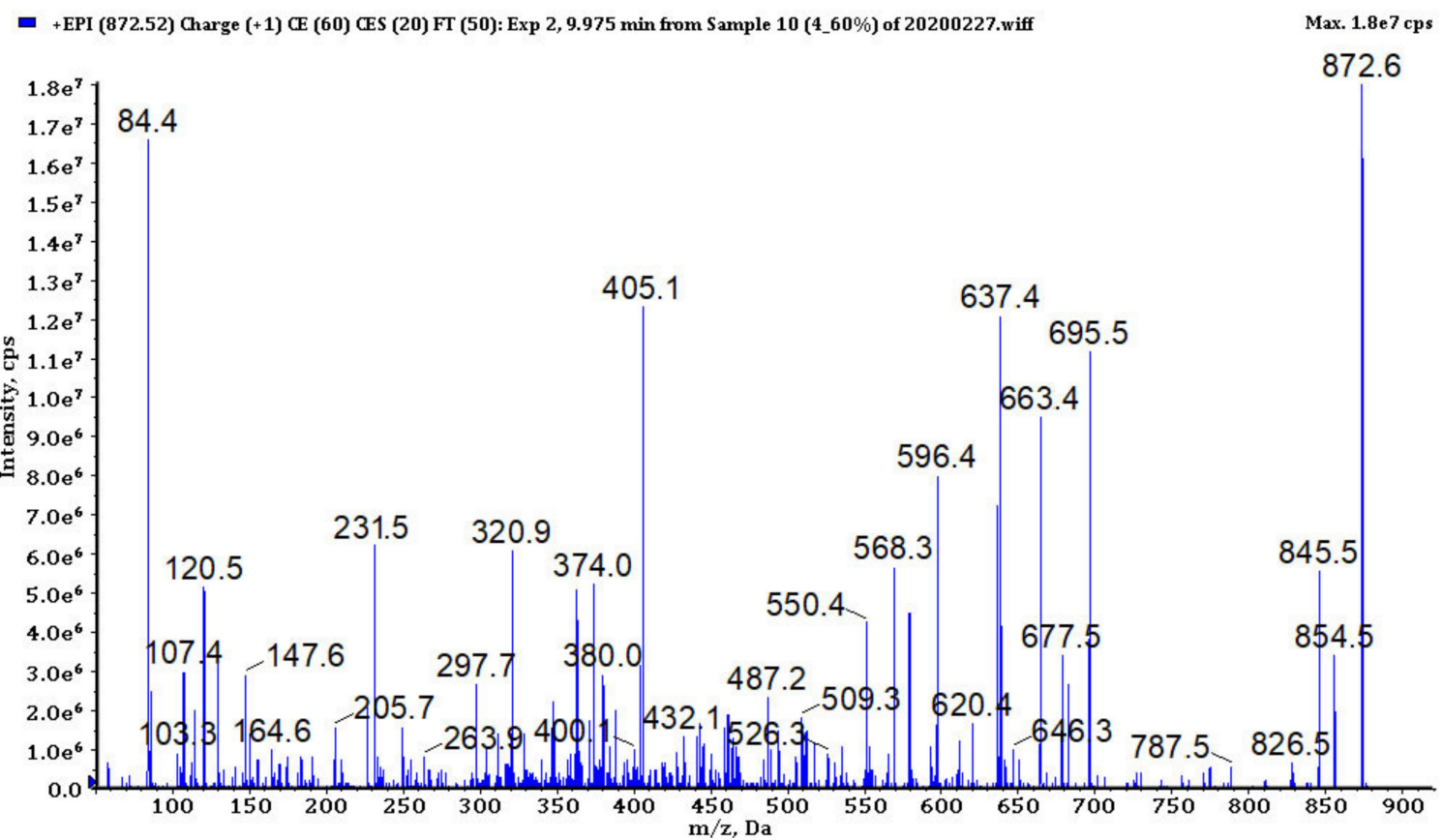

Figure 6. The enhanced product ion mass spectrum of anabaenopeptin AP871 with the suggested structure MeHTyr $+\mathrm{CO}$ $-[$ Lys $+\mathrm{Val}+\mathrm{Hty}+\mathrm{MeAla}+\mathrm{Phe}]$ and the following fragment ions: $m / z 872[\mathrm{M}+\mathrm{H}]^{+}, 854\left[\mathrm{M}+\mathrm{H}-\mathrm{H}_{2} \mathrm{O}\right]^{+}, 845[\mathrm{M}+\mathrm{H}$ $-\mathrm{CO}^{+}, 826\left[\mathrm{M}+\mathrm{H}-\mathrm{H}_{2} \mathrm{O}-\mathrm{CO}\right]^{+}, 787[\mathrm{M}+\mathrm{H}-\mathrm{MeAla}]^{+}, 773[\mathrm{M}+\mathrm{H}-\mathrm{Val}]^{+}, 695[\mathrm{M}+\mathrm{H}-\mathrm{HTyr}]^{+}, 663[\mathrm{M}+\mathrm{H}-$ $\left.\mathrm{MeHTyr}-\mathrm{H}_{2} \mathrm{O}\right]^{+}, 596[\mathrm{M}+\mathrm{H}-(\mathrm{HTyr}+\mathrm{Val})]^{+}, 578\left[\mathrm{M}+\mathrm{H}-(\mathrm{HTyr}+\mathrm{Val})-\mathrm{H}_{2} \mathrm{O}\right]^{+}, 568[\mathrm{M}+\mathrm{H}-(\mathrm{HTyr}+\mathrm{Val})-\mathrm{CO}]^{+}$, $550\left[\mathrm{M}+\mathrm{H}-(\mathrm{HTyr}+\mathrm{Val})-\mathrm{H}_{2} \mathrm{O}-\mathrm{CO}\right]^{+}, 405[\mathrm{HTyr}+\mathrm{Val}+\mathrm{Lys}+\mathrm{H}]^{+}, 263[\mathrm{MeAla}+\mathrm{HTyr}+\mathrm{H}]^{+}, 231[\mathrm{MeAla}+\mathrm{Phe}-$ $\mathrm{H}]^{+}, 164$ MeHTyr immonium, 120 Phe immonium, 58 MeAla immonium, 84 Lys.

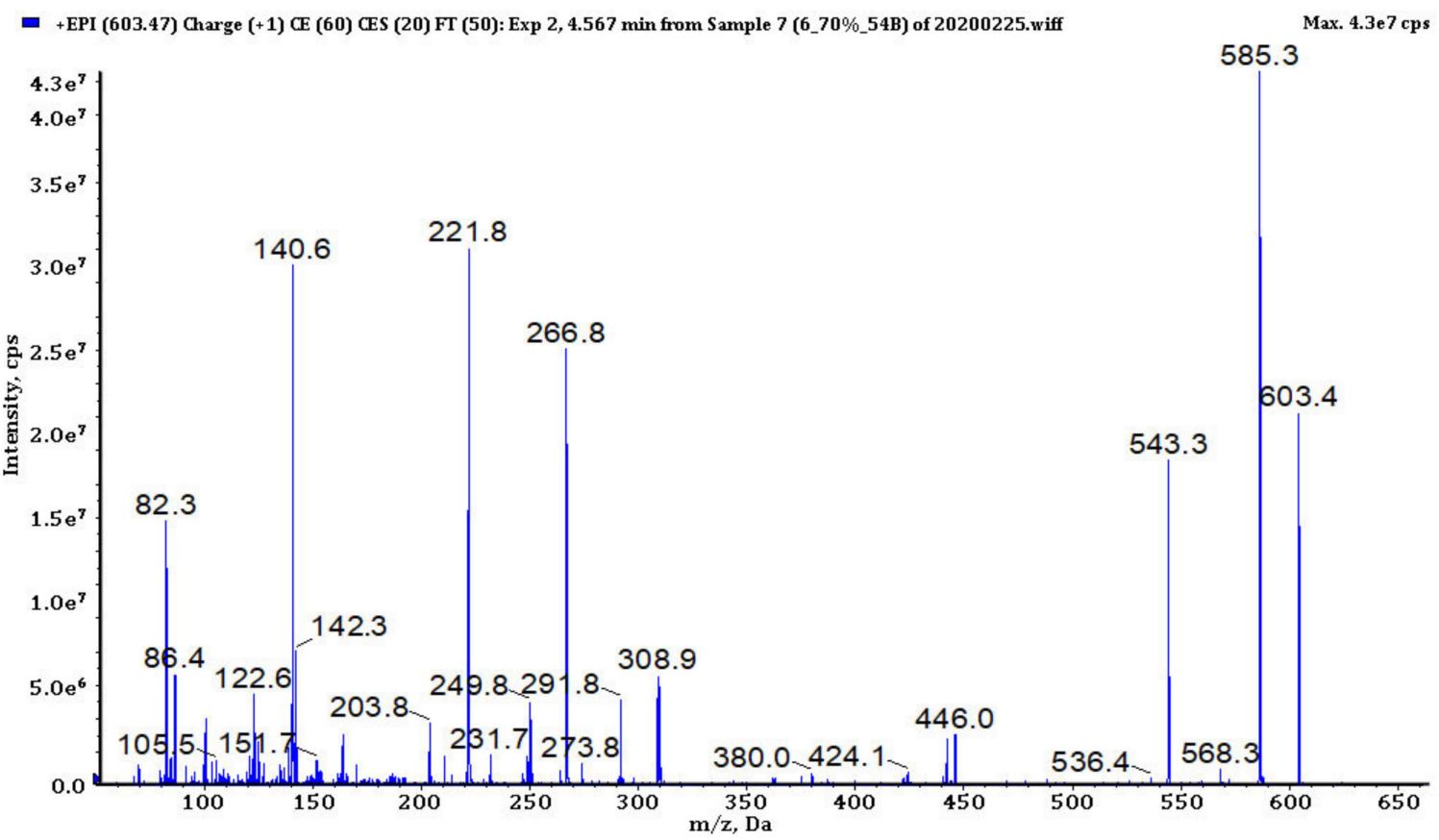

Figure 7. The enhanced product ion mass spectrum of aeruginosin K139 with the structure Hpla + Ile + Choi + Argal and the following fragment ions: $m / z 603[\mathrm{M}+\mathrm{H}]^{+}, 585\left[\mathrm{M}+\mathrm{H}-\mathrm{H}_{2} \mathrm{O}\right]^{+}, 543\left[\mathrm{M}+\mathrm{H}-\mathrm{CH}_{2} \mathrm{~N}_{2}-\mathrm{H}_{2} \mathrm{O}\right]^{+}, 446[\mathrm{M}+\mathrm{H}$ - Argal $^{+}, 308\left[\text { Choi }+ \text { Argal }+\mathrm{H}-\mathrm{NH}_{3}\right]^{+}, 291\left[\text { Choi }+ \text { Argal }+\mathrm{H}-\mathrm{NH}_{2}-\mathrm{H}_{2} \mathrm{O}\right]^{+}, 266\left[\mathrm{Choi}+\mathrm{Argal}+\mathrm{H}-\mathrm{CH}_{3} \mathrm{~N}_{2}\right.$ $\left.-\mathrm{H}_{2} \mathrm{O}\right]^{+}, 122$ and 140 Choi ions, 142 Argal, 86 Leu immonium (Choi - 2-carboxy-6-hydroxyoctahydroindol, Hpla (4-hydroxy)phenyllactic acid)). 
The detection of CPs in the samples was based on spectral data published by Fuji et al. [45], Welker et al. [26,46] and Czarnecki et al. [47]. Structures of the peptides were mainly recognized by the ion peaks at $m / z$ 420, 308, 234, 215, 150 (MeTyr immonium ion) and 120 (Phe immonium ion) that indicate the presence of Ahp + Phe + MeTyr fragment (Figure 3, Figures S3-S5; Ahp-3-amino-6-hydroxy-2-piperidone). In eight CPs (CP1012, CP993, CP986, CP984, CP965, CP951, CP911 and CP886) the substitution of chloride ion at MeTyr was detected by the shift of the peaks at $m / z$ 420, 308 and 150 to $m / z$ 454, 342 and 184 . In few CPs spectra, the ion peaks at $m / z$ 386, 274, 209, 181 and 86 that are characteristic for Ahp + Leu + MeTyr were observed. All Tyr ${ }^{2}$-containing CPs were detected as dehydrated protonated molecules $\left[\mathrm{M}+\mathrm{H}-\mathrm{H}_{2} \mathrm{O}\right]^{+}$(Figure 3).

The fragmentation spectra of MCs detected in samples from the Curonian Lagoon were compared with those published by other authors [48-50]. Based on the analysis (Figure 4, Figure S6) and the comparison of the spectra, we concluded that the detected MCs belong to the known MC variants previously described by Bouaïcha et al. [51] and included in CyanoMetDB [52]. Structure elucidation of MGs was mainly based on mass fragmentation spectra of the compounds published by Zervou et al. [53] and Carneiro et al. [54] and on the description of the important diagnostic ions of the peptides included in the work (e.g., $m / z 128$ for 3-amino-2-hydroxy-decanoic acid Ahda or $m / z 142$ for MeAhda). The process of structure elucidation of a new MGs variant, MG753, is illustrated in Figure 5 (Figure S7, Figure S8; MG928, MG783, respectively). In structure elucidation of APs, the fragmentation spectra published by Erhard et al. [55], Welker et al. [26] and Spoof et al. [56] were useful. The spectra always contained the peak at $m / z 84$ derived from the conserved Lys (Figure 6, Figures S9-S11). The kind of residue in a side chain was deduced based on the intensive ion peak at $m / z[\mathrm{M}+\mathrm{H}-(\mathrm{Arg} / \mathrm{Tyr} / \mathrm{Ile}-\mathrm{CO})]$. The presence of Arg in this position was additionally confirmed by peaks at $m / z 201$ and 175 . The MS/MS spectrum of AP871 and the description of the most characteristic fragment ions are shown in Figure 6. The fragmentation spectra of AERs were compared with those published by other authors [57] and was recognized by the presence of ions at $m / z 140$ and 122 characteristic for 2-carboxy-6-hydroxyoctahydroindole (Choi), and peaks at $m / z 266$, 291 and 308 indicating the presence of Choi + Argal fragment (Figure 7, Figure S12; 603, 619 , respectively).

In the fractions eluted with the solution containing the highest content of organic solvent (i.e., methanol) (70-100) obtained from extracts IV and V, CPs and MGs constituted the dominant classes of peptides, with the highest number of detected variants, while the most intensive ion peaks in LC-MS chromatograms were observed for AERs and CPs (Table S9, Figures S2a-d). Of these, AER604 had the most intensive ion peak in the chromatograms of fractions IV-70 and V-70. In the fraction IV-80, only variant CP1006 was detected, while in the chromatogram of fraction V-90-CP1014 gave the most intensive ion peak. In the subfraction IV-70-90 the most intensive ion peaks in LC-MS chromatogram were observed for CPs, with CP1015 characterizes by the most intensive peak (Table S9, Figure S2e).

In the fractions (40-100) obtained from extracts VIII and IX, a high number of CPs variants were detected. High diversity of MGs was detected in the fractions VIII-80 and VIII-90, too. However, AERs, and especially AER567, gave the most intensive ion peaks in LC-MS chromatograms of the samples (Table S9, Figure S2f-j).

\section{Discussion}

Within this study, enzymatic, antimicrobial and cytotoxicity bioassays revealed high bioactivity of phytoplankton field samples collected from the Curonian Lagoon. Our results also showed that species diversity of phytoplankton, especially cyanobacteria, had a significant effect on the different bioactivity results. Bacillariophyta and Chlorophyta, two dominating phytoplankton groups did not differ in species diversity throughout the bioactive samples, while Cyanophyta species composition differed significantly. This fact suggests that secondary metabolites produced by cyanobacteria potentially may have had 
a greater influence on the bioactivity results than the compounds produced by eukaryotic microalgae. Unfortunately, as complex bloom samples were analyzed, no reliable conclusion about the link between the observed activity and a specific sample component can be established. As in the study, the LC-MS/MS method optimized for cyanopeptide analysis was used, numerous compounds from this group of natural products could be detected. A list of 117 cyanopeptides is presented in Table S2. CPs were found to be the dominant and one of the most structurally diverse class of cyanopeptides. Peptides representing other classes, i.e., AERs, APs, MGs, MCs, were 3-4-fold less numerous in different variants. The composition of cyanopeptides in the environment highly depends on the diversity of cyanobacteria species and their genetic ability to effectively biosynthesize these metabolites under various biotic and abiotic conditions [52,58-60].

During our study the ecological significance of phytoplankton metabolites was assessed using extracts and fractions obtained from field samples. The samples were tested with the application of different environmental bacterial strains and D. magna. The activity of extracts against D. magna was rather weak-even after $48 \mathrm{~h}$ of incubation more than $50 \%$ of the individuals survived (except extract I obtained from Sample 1). Daphnia sp. is an important organism in the food chains; it grazes on phytoplankton organisms [61]. In many acute toxicity assays, relatively high concentrations of samples are used, which do not always reflect the real situation in the aquatic environment. These conditions might potentially correspond periods of phytoplankton blooms or their final stages, when cells collapse, and concentrations of the dissolved secondary metabolites increases significantly. Such conditions could have a negative effect on aquatic organisms (including zooplankton) $[62,63]$. However, during non-bloom periods, zooplankton uses mechanisms that help to maintain persistent coexistence of both groups (cyanobacteria or microalgae and zooplankton). According to the literature, the zooplankton response to microalgae may vary between species or strains. Moreover, zooplankton has detoxification mechanisms to minimize the negative effects of cyanobacteria [64]. In our study the concentrations of extracts used for acute toxicity assay potentially reflected non-bloom conditions and it is possible that the defense mechanisms were effective enough for the organisms to support their survival.

In terms of the antibacterial assays, the growth of almost all environmental bacterial strains, except antibiotic-resistant $V$. cholerae 2329 , was inhibited by the tested samples (Table 2). The tests revealed the ability of phytoplankton species to produce antibacterial compounds potently active against environmental, naturally occurring A. salmonicida and $V$. diazotrophicus. These compounds might constitute an element of a defense strategy and increase the survivorship of the producer in extremely competitive environments where a huge variety of bacteria and other microbes co-exists [28,65]. In the case of $V$. cholerae 2329 , no inhibition or even growth stimulation was observed during our study. Vibrio are naturally occurring marine and brackish water bacteria and their intensive proliferation mostly correlates with temperature $\left(>20^{\circ} \mathrm{C}\right)$ and salinity (5-10 ppt) [66]. It is known that several species of Vibrio are pathogenic and may cause toxigenic cholera and vibriosis [67]. In natural water bodies, rising water temperature [68], which is one of the major causes of cyanobacterial blooms and proliferation [69,70], may also provide an optimal environment for the occurrence of Vibrio species [66,71]. Moreover, the dissolved organic matter resulting from intensive phytoplankton blooms, especially cyanobacteria-derived organic matter, can significantly support the growth of potentially pathogenic Vibrio species [71-73]. Such synergy between cyanobacteria and Vibrio should be monitored as an element of bathing water quality assessment [74].

Along with the ecological significance, the investigations into the diversity, biological activities of natural products and their specific biotechnological applications were important elements of the study. In the assays, the inhibition of antibiotic-resistant E. faecium 45, isolated from the Sewage Treatment Plant, was observed (Table 2). The extracts were more active against $E$. faecium 45 than the tested fractions. It is believed that in some cases the mixtures of bioactive secondary metabolites could act more efficiently, compared with 
separated (or pure) metabolites. Such effects can be attributed to additive or synergistic interactions between many different compounds [75]. Moreover, the sample processing may lead to the loss of activity as a consequence of compound degradation or modification. The nutrients removal efficiencies in wastewater treatment plants based on cyanobacteria or microalgae species are well documented [76], while their role and efficiency in pathogen removal are still under investigation [77]. The wastewater treatment systems do not entirely eliminate antibiotic-resistant strains of enterococci in the treated water [77,78], therefore phytoplankton species, or especially cyanobacteria, might assist in reducing pathogens and fecal bacteria present in wastewaters.

Pharmacy is another important field where the application of natural products has great potential $[79,80]$. Extracts and fractions tested during our study revealed antibacterial activity against clinical, antibiotic-resistant bacterial strains (Tables 2 and 4). Antibacterial activity of eukaryotic microalgae and cyanobacteria extracts, containing different classes of metabolites, is quite often reported in other studies [17,42,81]. During our study, the fractions eluted from solid-phase extraction cartridge with the more hydrophobic solvent (70-100\% methanol in MiliQ water) were active against antibiotic-resistant Gram-positive bacteria. The mechanisms of action of cyanobacterial and microalgal metabolites against bacterial cells are not well described [82]. It has been proposed that the resistance of Gram-negative bacteria to metabolites produced by cyanobacteria is due to a hydrophilic outer membrane that blocks the penetration of hydrophobic metabolites through the cell membrane [83].

Our results also revealed high inhibitory activity of the tested extracts and fractions against serine proteases, trypsin, chymotrypsin and thrombin (Tables 3 and 4); activity against T47D cells also confirmed pharmaceutical potential of phytoplankton natural products. Serine proteases have different roles related to human health (digestion, immune response or blood coagulation) [84]. Cyanobacterial secondary metabolites, such as CPs and AERs are generally considered to be the main classes of cyanopeptides responsible for the inhibition of serine proteases $[26,58,85,86]$. CPs and related depsipeptides also have cytotoxic activities [87]. Amongst CPs, microcystilide A showed cell-differentiation-promoting activity using HL-60 human leucocytes [88]. Research done by Salem et al. [89], showed that Microcystis extracts containing CPs, MGs and other metabolites were active against HepG-2, colon CaCO-2 and breast MCF-7 cancer cell lines. Additionally, MGs congeners showed the cytotoxic effect. The compounds were active towards human hepatocellular carcinoma (HepG2) cell line and had genotoxic activity [90]. MGs are also known to be angiotensin-converting enzyme (ACE) inhibitors [91], leucine aminopeptidase, aminopeptidase $\mathrm{M}$, bovine aminopeptidase $\mathrm{N}$ and trypsin inhibitors [92,93]. Metabolites produced by other organisms present in bloom samples were also reported to have interesting biological activities. For example, the extracts of Nitzschia (diatom) cells exhibited ACE-inhibitory activity [94]; sulfolipids, isolated from several species of Scenedesmus (green microalgae) were effective in inhibiting alpha-glucosidase, glutaminyl-peptide cyclotransferase and telomerase [95]. Diatoms are considered to be a source of promising anticancer agents, such as Synedra acus produce chrysolaminaran, which exhibits HT-29 and DLD-1 colon cancer cells [96]; the extracts of Melosira and Nitzschia induce IPC-81 leukemia cell death [97].

Our results support the idea that the biodiscovery of new compounds in the environment that have dynamic conditions (lagoons, estuaries) provides a relatively high diversity of bioactive metabolites with biotechnological potential [28]. The promising results obtained in this work, encourage us for further studies into the structure, activity and application of specific metabolites produced by microorganisms isolated from Curonian Lagoon.

Supplementary Materials: The following are available online at https: / www.mdpi.com/article / 10.3390/biom11081139/s1, Figure S1: Phytoplankton abundance and biomass analysis, Figure S1: nMDS plot based on presence/absence Jaccard similarity matrix of Bacillariophyta (a), Chlorophyta (b) and Cyanophyta (c) communities, Figure S2: The total ion current (TIC) spectra of fractions from phytoplankton samples: IV-70 (a), IV-80 (b), V-70 (c), V-90 (d), IV-70-90 (e), VIII-70 (f), VIII-80 (g), 
IX-40 (h), IX-50 (i), IX-80 (j), Figure S3: The enhanced product ion mass spectrum of cyanopeptoline CP1055 with the suggested structure OA $+\mathrm{Gln}-\left[\mathrm{Thr}^{1}+\mathrm{Tyr}^{2}+\mathrm{Ahp}^{3}+\mathrm{Phe}^{4}+\mathrm{MeTyr}^{5}+\mathrm{Val}^{6}\right]$ and the following fragment ions: $m / z 939\left[\mathrm{M}+\mathrm{H}-\mathrm{H}_{2} \mathrm{O}-\mathrm{Val}^{+}, 861\left[\mathrm{M}+\mathrm{H}-\mathrm{H}_{2} \mathrm{O}-\mathrm{MeTyr}\right]^{+}, 783\right.$ $\left[\mathrm{M}+\mathrm{H}-\mathrm{H}_{2} \mathrm{O}-(\mathrm{OA}+\mathrm{Gln})\right]^{+}, 765\left[\mathrm{M}+\mathrm{H}-2 \mathrm{H}_{2} \mathrm{O}-(\mathrm{OA}+\mathrm{Gln})\right]^{+}, 666\left[\mathrm{M}+\mathrm{H}-2 \mathrm{H}_{2} \mathrm{O}-(\mathrm{OA}\right.$ $+\mathrm{Gln})-\mathrm{Val}^{+}, 420\left[\mathrm{Ahp}+\mathrm{Phe}+\mathrm{MeTyr}+\mathrm{H}-\mathrm{H}_{2} \mathrm{O}^{+}, 150 \mathrm{MeTyr}\right.$ immonium; 136 Tyr immonium; 120 Phe immonium (OA - octanoic acid), Figure S4: The enhanced product ion mass spectrum of cyanopeptoline CP1012 with the suggested structure Ac $+\mathrm{Gln}-\left[\mathrm{Thr}^{1}+\mathrm{Arg}^{2}+\mathrm{Ahp}^{3}+\mathrm{Phe}^{4}+\right.$ ClMeTyr $\left.{ }^{5}+\mathrm{Ile}^{6}\right]$ and the following fragment ions: $m / z 1013[\mathrm{M}+\mathrm{H}]^{+}, 995\left[\mathrm{M}+\mathrm{H}-\mathrm{H}_{2} \mathrm{O}\right]^{+}, 967[\mathrm{M}$ $\left.+\mathrm{H}-\mathrm{H}_{2} \mathrm{O}-\mathrm{CO}\right]^{+}, 882\left[\mathrm{M}+\mathrm{H}-\mathrm{H}_{2} \mathrm{O}-\mathrm{Ile}\right]^{+}, 864\left[\mathrm{M}+\mathrm{H}-2 \mathrm{H}_{2} \mathrm{O}-\mathrm{Ile}\right]^{+}, 842\left[\mathrm{M}+\mathrm{H}-\mathrm{H}_{2} \mathrm{O}-\right.$ $(\mathrm{Ac}+\mathrm{Gln})]^{+}, 824\left[\mathrm{M}+\mathrm{H}-2 \mathrm{H}_{2} \mathrm{O}-(\mathrm{Ac}+\mathrm{Gln})\right]^{+}, 796\left[\mathrm{M}+\mathrm{H}-2 \mathrm{H}_{2} \mathrm{O}-(\mathrm{Ac}+\mathrm{Gln})-\mathrm{CO}\right]^{+}, 455$ $\left[\mathrm{Ahp}+\mathrm{Phe}+\mathrm{ClMeTyr}+\mathrm{H}-\mathrm{H}_{2} \mathrm{O}^{+}, 428\left[\mathrm{Ac}+\mathrm{Gln}+\mathrm{Thr}+\mathrm{Arg}+\mathrm{H}^{+}, 184 \mathrm{ClMeTyr}\right.\right.$ immonium; 120 Phe immonium (Ac - acetyl group), Figure S5: The enhanced product ion mass spectrum of cyanopeptoline CP986 with the suggested structure HA + Gln $-\left[\mathrm{Thr}^{1}+\mathrm{Arg}^{2}+\mathrm{Ahp}^{3}+\mathrm{Leu}^{4}+\right.$ MeTyr $\left.{ }^{5}+\mathrm{Val}^{6}\right]$ and the following fragment ions: $m / z 987[\mathrm{M}+\mathrm{H}]^{+}, 969\left[\mathrm{M}+\mathrm{H}-\mathrm{H}_{2} \mathrm{O}\right]^{+}, 941[\mathrm{M}+$ $\mathrm{H}-\mathrm{H}_{2} \mathrm{O}-\mathrm{CO}^{+}, 870\left[\mathrm{M}+\mathrm{H}-\mathrm{HA}-\mathrm{H}_{2} \mathrm{O}\right]^{+}, 760[\mathrm{M}+\mathrm{H}-(\mathrm{HA}+\mathrm{Gln})]^{+}, 742[\mathrm{M}+\mathrm{H}-(\mathrm{HA}+$ $\left.\mathrm{Gln})-\mathrm{H}_{2} \mathrm{O}\right]^{+}, 714\left[\mathrm{M}+\mathrm{H}-(\mathrm{HA}+\mathrm{Gln})-\mathrm{H}_{2} \mathrm{O}-\mathrm{CO}^{+}, 584[\mathrm{M}+\mathrm{H}-(\mathrm{Ahp}+\mathrm{Leu}+\mathrm{MeTyr})]^{+}, 484\right.$ $[\mathrm{HA}+\mathrm{Gln}+\mathrm{Thr}+\mathrm{Arg}+\mathrm{H}]^{+}, 386\left[\mathrm{Ahp}+\mathrm{Ile}+\mathrm{MeTyr}+\mathrm{H}-\mathrm{H}_{2} \mathrm{O}\right]^{+}, 209\left[\mathrm{Ahp}+\mathrm{Ile}+\mathrm{H}-\mathrm{H}_{2} \mathrm{O}\right]^{+}$, $181\left[\mathrm{Ahp}+\mathrm{Ile}+\mathrm{H}-\mathrm{H}_{2} \mathrm{O}-\mathrm{CO}^{+}, 150 \mathrm{MeTyr}\right.$ immonium, 136 Tyr immonium, 86 Ile immonium (HA - hexanoic acid), Figure S6: The enhanced product ion mass spectrum of microcystin [Ser ${ }^{1}$ ]MC - HTyrR with the structure Adda $-[$ Glu + Mdha + Ser + HTyr + MeAsp + Arg] and the following fragment ions: $m / z 941\left[\mathrm{M}+\mathrm{H}-\right.$ Adda $^{+}, 923\left[\mathrm{C}_{11} \mathrm{H}_{14} \mathrm{O}+\mathrm{Glu}+\mathrm{Mdha}+\mathrm{Ser}+\mathrm{HTyr}+\mathrm{MeAsp}+\right.$ Arg $+\mathrm{H}]^{+}, 918[\text { Adda }+\mathrm{Glu}+\mathrm{Mdha}+\mathrm{Ser}+\mathrm{HTyr}+\mathrm{MeAsp}+\mathrm{H}]^{+}, 863[\mathrm{Ser}+\mathrm{HTyr}+\mathrm{MeAsp}+\mathrm{Arg}$ + Adda $+\mathrm{H}]^{+}, 728[\mathrm{MeAsp}+\mathrm{Arg}+\mathrm{Adda}+\mathrm{Glu}+\mathrm{H}]^{+}, 682[\mathrm{Arg}+\mathrm{Adda}+\mathrm{Glu}+\mathrm{Mdha}+\mathrm{H}]^{+}, 633$ $[\mathrm{Mdha}+\mathrm{Ser}+\mathrm{HTyr}+\mathrm{MeAsp}+\mathrm{Arg}+\mathrm{H}]^{+}, 599[\mathrm{Arg}+\mathrm{Adda}+\mathrm{Glu}+\mathrm{H}]^{+}, 550[\mathrm{Ser}+\mathrm{HTyr}+\mathrm{MeAsp}$ $+\mathrm{Arg}+\mathrm{H}]^{+}, 470[\mathrm{Arg}+\mathrm{Adda}+\mathrm{H}]^{+}, 375\left[\mathrm{C}_{11} \mathrm{H}_{14} \mathrm{O}+\mathrm{Glu}+\mathrm{Mdha}+\mathrm{H}\right]^{+}, 213[\mathrm{Glu}+\mathrm{Mdha}+\mathrm{H}]^{+}, 135$ Adda fragment, Figure S7: The enhanced product ion mass spectrum of microginin MG928 with the suggested structure MeAhda + Phe + MeLeu + HTyr + Pro + Tyr and the following fragment ions: $m / z 929[\mathrm{M}+\mathrm{H}]^{+}, 748[\mathrm{M}+\mathrm{H}-\mathrm{Tyr}]^{+}, 651[\mathrm{M}+\mathrm{H}-(\mathrm{Tyr}+\mathrm{Pro})]^{+}, 633[\mathrm{M}+\mathrm{H}-($ Pro + Tyr $)-$ $\left.\mathrm{H}_{2} \mathrm{O}\right]^{+}, 474[\mathrm{M}+\mathrm{H}-(\mathrm{HTyr}+\mathrm{Pro}+\mathrm{Tyr})]^{+}, 456\left[\mathrm{M}+\mathrm{H}-(\mathrm{HTyr}+\mathrm{Pro}+\mathrm{Tyr})-\mathrm{H}_{2} \mathrm{O}\right]^{+}, 348[\mathrm{MeAhda}$ $+\mathrm{Phe}+\mathrm{H}]^{+}, 330\left[\mathrm{MeAhda}+\mathrm{Phe}+\mathrm{H}-\mathrm{H}_{2} \mathrm{O}\right]^{+}, 182\left[\mathrm{MeAhda}-\mathrm{H}_{2} \mathrm{O}\right]^{+}, 172[\mathrm{MeAhda}-\mathrm{CO}]^{+}, 150$ Hty immonium ion, 142 MeAhda fragment, 120 Phe immonium, 100 MeLeu immonium, Figure S8: The enhanced product ion mass spectrum of microginin MG783 with the suggested structure MeAhda + Val + MeLeu + HTyr + Tyr and the following fragment ions: $m / z 784[\mathrm{M}+\mathrm{H}]^{+}, 603[\mathrm{M}+$ $\mathrm{H}-\mathrm{Tyr}]^{+}, 426[\mathrm{M}+\mathrm{H}-(\mathrm{HTyr}+\mathrm{Tyr})]^{+}, 408\left[\mathrm{M}+\mathrm{H}-(\mathrm{HTyr}+\mathrm{Tyr})-\mathrm{H}_{2} \mathrm{O}\right]^{+}, 299[\mathrm{M}+\mathrm{H}-(\mathrm{MeLeu}$ $+\mathrm{HTyr}+\mathrm{Tyr})]^{+}, 281\left[\mathrm{M}+\mathrm{H}-(\mathrm{MeLeu}+\mathrm{Htyr}+\mathrm{Tyr})-\mathrm{H}_{2} \mathrm{O}\right]^{+}, 182\left[\mathrm{MeAhda}-\mathrm{H}_{2} \mathrm{O}\right]^{+}, 172[\mathrm{MeAhda}$ $-\mathrm{CO}^{+}, 142 \mathrm{MeAhda}$ fragment, $100 \mathrm{MeLeu}$, Figure S9: The enhanced product ion mass spectrum of anabaenopeptin AP885CL with the suggested structure MeHTyr + CO - [Lys + Ile + Hty + MeAla + Phe $]$ and the following fragment ions: $m / z 886[\mathrm{M}+\mathrm{H}]^{+}, 868\left[\mathrm{M}+\mathrm{H}-\mathrm{H}_{2} \mathrm{O}\right]^{+}, 858[\mathrm{M}+\mathrm{H}-$ $\mathrm{CO}^{+}, 773[\mathrm{M}+\mathrm{H}-\mathrm{Ile}]^{+}, 709\left[\mathrm{M}+\mathrm{H}-\mathrm{HTyr}^{+}, 691\left[\mathrm{M}+\mathrm{H}-\mathrm{HTyr}-\mathrm{H}_{2} \mathrm{O}\right]^{+}, 651[\mathrm{M}+\mathrm{H}-(\mathrm{CO}+\right.$ $\mathrm{MeHTyr})]^{+}, 633\left[\mathrm{M}+\mathrm{H}-(\mathrm{CO}+\mathrm{MeHTyr})-\mathrm{H}_{2} \mathrm{O}\right]^{+}, 405[\mathrm{M}+\mathrm{H}-\mathrm{MeHTyr}-(\mathrm{Hty}+\mathrm{Ile})]^{+}, 320[\mathrm{M}+$ $\mathrm{H}-\mathrm{MeHTyr}-(\mathrm{MeAla}+\mathrm{Hty}+\mathrm{Ile})]^{+}, 263[\mathrm{MeAla}+\mathrm{Hty}+\mathrm{H}]^{+}, 120$ Phe immonium, $107 \mathrm{Tyr} / \mathrm{HTyr}$, 84 Lys, Figure S10: The enhanced product ion mass spectrum of anabaenopeptin AP841CL with the suggested structure Tyr $+\mathrm{CO}-[\mathrm{Lys}+\mathrm{Ile}+\mathrm{Hph}+\mathrm{MeAla}+\mathrm{Phe}]$ and the following fragment ions: $m / z 842[\mathrm{M}+\mathrm{H}]^{+}, 824\left[\mathrm{M}+\mathrm{H}-\mathrm{H}_{2} \mathrm{O}\right]^{+}, 814[\mathrm{M}+\mathrm{H}-\mathrm{CO}]^{+}, 729[\mathrm{M}+\mathrm{H}-\mathrm{Ile}]^{+}, 681[\mathrm{M}+\mathrm{H}-\mathrm{Hph}]^{+}$, $661\left[\mathrm{M}+\mathrm{H}-\mathrm{Tyr}-\mathrm{H}_{2} \mathrm{O}\right]^{+}, 635[\mathrm{M}+\mathrm{H}-(\mathrm{CO}+\mathrm{Tyr})]^{+}, 405[\mathrm{M}+\mathrm{H}-\mathrm{Tyr}-(\mathrm{Hph}+\mathrm{Ile})]^{+}, 387[\mathrm{M}+\mathrm{H}$ $\left.-\mathrm{Tyr}-(\mathrm{Hph}+\mathrm{Ile})-\mathrm{H}_{2} \mathrm{O}\right]^{+}, 320[\mathrm{M}+\mathrm{H}-\mathrm{Tyr}-(\mathrm{MeAla}+\mathrm{Hph}+\mathrm{Ile})]^{+}, 247[\mathrm{MeAla}+\mathrm{Hph}+\mathrm{H}]^{+}$, 120 Phe immonium, 84 Lys, Figure S11: The enhanced product ion mass spectrum of anabaenopeptin AP915 with the suggested structure Tyr + CO - [Lys + Val + HTyr + MeHTyr + Ile] and the following fragment ions: $m / z 916\left[\mathrm{M}+\mathrm{H}^{+}, 898\left[\mathrm{M}+\mathrm{H}-\mathrm{H}_{2} \mathrm{O}\right]^{+}, 888[\mathrm{M}+\mathrm{H}-\mathrm{CO}]^{+}, 817[\mathrm{M}+\mathrm{H}-\mathrm{Val}]^{+}\right.$, $803\left[\mathrm{M}+\mathrm{H}-\mathrm{Ile}^{+}, 739[\mathrm{M}+\mathrm{H}-\mathrm{HTyr}]^{+}, 721\left[\mathrm{M}+\mathrm{H}-\mathrm{HTyr}-\mathrm{H}_{2} \mathrm{O}\right]^{+}, 725\left[\mathrm{M}+\mathrm{H}-\mathrm{MeHTyr}^{+}\right.\right.$, $709[\mathrm{M}+\mathrm{H}-(\mathrm{CO}+\mathrm{Tyr})]^{+}, 612[\mathrm{M}+\mathrm{H}-(\mathrm{MeHTyr}+\mathrm{Ile})]^{+}, 477[\mathrm{M}+\mathrm{H}-\mathrm{Tyr}-(\mathrm{HTyr}+\mathrm{Val})]^{+}, 369$ $[\mathrm{MeHTyr}+\mathrm{HTyr}+\mathrm{H}]^{+}, 305[\mathrm{MeHTyr}+\mathrm{Ile}+\mathrm{H}]^{+}, 164$ MeHTyr immonium, 84 Lys, Figure S12: The enhanced product ion mass spectrum of aeruginosin AER618 with the suggested structure Hpla + $\mathrm{Leu} / \mathrm{Ile}+\mathrm{Choi}+$ Arg and the following fragment ions: $m / z 619[\mathrm{M}+\mathrm{H}]^{+}, 601\left[\mathrm{M}+\mathrm{H}-\mathrm{H}_{2} \mathrm{O}\right]^{+}$, $559\left[\mathrm{M}+\mathrm{H}-\mathrm{H}_{2} \mathrm{O}-\mathrm{CH}_{2} \mathrm{~N}_{2}\right]^{+}, 455[\mathrm{M}+\mathrm{H}-\mathrm{Hpla}]^{+}, 325\left[\mathrm{Choi}+\mathrm{Arg}+\mathrm{H}-\mathrm{NH}_{3}\right]^{+}, 307[\mathrm{Choi}+$ $\left.\mathrm{Arg}+\mathrm{H}-\mathrm{NH}_{3}-\mathrm{H}_{2} \mathrm{O}\right]^{+}, 282\left[\mathrm{Choi}+\mathrm{Arg}+\mathrm{H}-\mathrm{CH}_{2} \mathrm{~N}_{2}-\mathrm{H}_{2} \mathrm{O}\right]^{+}, 70$ and $175 \mathrm{Arg}, 122$ and 140 Choi ions, $86 \mathrm{Leu} /$ Ile immonium, Table S1: Bacterial strains used in the antibacterial activity assay, 
Table S2: Microcystins and other oligopeptides detected in the fractions obtained from the Curonian Lagoon. Red color indicates active fractions; $X$ indicates non-determined amino acids; empty cellsmicrocystins and other oligopeptides not detected, Table S3: Antibacterial activity of extracts obtained from Curonian Lagoon phytoplankton. Results are expressed as a percentage of bacterial culture OD value compared to untreated control (100\% growth). Different colors highlight the differences in OD values of bacterial cultures (the color code is explained below the table), Table S4: Enzyme inhibition, cytotoxicity activity, and acute toxicity of phytoplankton extracts. Results are expressed as a percentage value of enzyme inhibition, cell viability (cytotoxicity assay) and cladocerans viability (acute toxicity assay), compared to untreated control. Different colors highlight the differences in values (the color code is explained below the table), Table S5: Antibacterial activity of fractions obtained after further separation of the extracts IV and V. Results are expressed as a percentage of bacterial culture OD value compared to untreated control (100\% growth). Different colors highlight the differences in OD values of bacterial cultures (the color code is explained below the table), Table S6: Enzyme inhibition of fractions obtained after further separation of the extracts VIII and IX. Results are expressed as a percentage value of enzyme inhibition compared to untreated control. Different colors highlight the differences in values (the color code is explained below the table), Table S7: T47D cancer cells viability of fractions obtained after further separation of the extracts IV, and fractions IV-50, IV-60 and IV-70. Results are expressed as a range of percentage effect compared to untreated control. Different colors have been applied to highlight the differences in values (the color code is explained below the table), Table S8: Presence and dominance of phytoplankton species in the samples (1-9) from the Curonian lagoon. Cyanobacteria dominance was expressed as a percentage of total cyanobacteria biomass. The dominance of other species of phytoplankton was expressed as a percentage of total phytoplankton biomass. The color code is explained below the table. Table S9. Microcystins (MCs) and other oligopeptides detected in the most active fractions obtained from the phytoplankton samples collected in the Curonian Lagoon (the numbers in parentheses are given to distinguish compounds with the same molar mass but different amino acid sequences).

Author Contributions: Conceptualization, D.O., H.M.-M. and A.T.-S.; Methodology, H.M.-M., A.T.S., M.C., K.S. and A.B.; Formal Analysis, D.O.; Investigation, D.O., H.M.-M., A.T.-S., M.C., K.S. and A.B.; Resources, R.P. and H.M.-M., Writing—Original Draft Preparation, D.O.; Writing-Review and Editing, H.M.-M., A.T.-S., M.C., K.S., A.B. and R.P.; Visualization, D.O.; Supervision, H.M.-M., A.T.-S. and R.P.; Funding Acquisition, R.P. and H.M.-M. All authors have read and agreed to the published version of the manuscript.

Funding: The research was funded by Lithuanian National Science Foundation, grant number S-MIP20-31, COST Action ES1408: European Network for Algal Bioproducts (EUALGAE) and COST Action CA18238: Ocean4Biotech, supported by COST (European Cooperation in Science and Technology) program. This work was also supported by Doctorate Study program in Ecology and Environmental Sciences, Marine Research Institute, Klaipeda University (for D.O.), Statutory Programme of the Institute of Oceanology PAS grant number II.3, by the National Science Centre in Poland grant number 2016/21/B/NZ9/02304 and a statutory program of the University of Gdańsk (grant No. DS/D531-G260-D424-19).

Data Availability Statement: Not applicable.

Acknowledgments: We gratefully thank to Greta Kilmonaite for preparation of map of the study area. We kindly thank for the Journal Editor and all the reviewers for their valuable comments.

Conflicts of Interest: The authors declare no conflict of interest.

\section{References}

1. Zilius, M.; Vybernaite-Lubiene, I.; Vaiciute, D.; Petkuviene, J.; Zemlys, P.; Liskow, I.; Voss, M.; Bartoli, M.; Bukaveckas, P.A. The Influence of Cyanobacteria Blooms on the Attenuation of Nitrogen Throughputs in a Baltic Coastal Lagoon. Biogeochemistry 2018, 141, 143-165. [CrossRef]

2. Vaičiūtè, D.; Bučas, M.; Bresciani, M.; Dabulevičienè, T.; Gintauskas, J.; Měžinè, J.; Tiškus, E.; Umgiesser, G.; Morkūnas, J.; de Santi, F.; et al. Hot Moments and Hotspots of Cyanobacteria Hyperblooms in the Curonian Lagoon (SE Baltic Sea) Revealed via Remote Sensing-Based Retrospective Analysis. Sci. Total Environ. 2021, 769. [CrossRef]

3. Lesutiene, J.; Bukaveckas, P.A.; Gasiunaite, Z.R.; Pilkaityte, R.; Razinkovas-Baziukas, A. Tracing the Isotopic Signal of a Cyanobacteria Bloom through the Food Web of a Baltic Sea Coastal Lagoon. Estuar. Coast. Shelf Sci. 2014, 138, 47-56. [CrossRef] 
4. Bartoli, M.; Zilius, M.; Bresciani, M.; Vaiciute, D.; Vybernaite-Lubiene, I.; Petkuviene, J.; Giordani, G.; Daunys, D.; Ruginis, T.; Benelli, S.; et al. Drivers of Cyanobacterial Blooms in a Hypertrophic Lagoon. Front. Mar. Sci. 2018, 5. [CrossRef]

5. Pilkaitytè, R.; Razinkovas, A. Seasonal Changes in Phytoplankton Composition and Nutrient Limitation in a Shallow Baltic Lagoon. Boreal Environ. Res. 2007, 12, 551-559.

6. Gasiūnaitè, Z.R.; Daunys, D.; Olenin, S.; Razinkovas, A. The Curonian Lagoon. In Ecology of Baltic Coastal Waters; Springer: Berlin/Heidelberg, Germany, 2008; pp. 197-215.

7. Overlingè, D.; Kataržytè, M.; Vaičiūtè, D.; Gyraite, G.; Gečaitè, I.; Jonikaitè, E.; Mazur-Marzec, H. Are There Concerns Regarding CHAB in Coastal Bathing Waters Affected by Freshwater-Brackish Continuum? Mar. Pollut. Bull. 2020, 159, 111500. [CrossRef] [PubMed]

8. Zilius, M.; Vybernaite-Lubiene, I.; Vaiciute, D.; Overlinge, D.; Griniene, E.; Zaiko, A.; Bonaglia, S.; Liskow, I.; Voss, M.; Andersson, A.; et al. Spatiotemporal Patterns of $\mathrm{N}_{2}$ Fixation in Coastal Waters Derived from Rate Measurements and Remote Sensing. Biogeosciences 2021, 18, 1857-1871. [CrossRef]

9. Šulčius, S.; Pilkaityte, R.; Mazur-Marzec, H.; KasperovičienE, J.; Ezhova, E.; Błaszczyk, A.; Paškauskas, R. Increased Risk of Exposure to Microcystins in the Scum of the Filamentous Cyanobacterium Aphanizomenon flos-aquae Accumulated on the Western Shoreline of the Curonian Lagoon. Mar. Pollut. Bull. 2015, 99, 264-270. [CrossRef] [PubMed]

10. Šulčius, S.; Montvydienė, D.; Mazur-Marzec, H.; Kasperovičienè, J.; Rulevičius, R.; Cibulskaitė, Ž. The Profound Effect of Harmful Cyanobacterial Blooms: From Food-Web and Management Perspectives. Sci. Total Environ. 2017, 609, 1443-1450. [CrossRef]

11. Montvydienè, D.; Šulčius, S.; Jurgelènè, Ž.; Makaras, T.; Kalcienè, V.; Taraškevičius, R.; Kazlauskas, M.; Kazlauskienė, N. Contrasting Ecotoxic Effects of Landfill Leachate and Cyanobacterial Biomass on Aquatic Organisms. Water Air Soil Pollut. 2020, 231. [CrossRef]

12. Paldavičienè, A.; Mazur-Marzec, H.; Razinkovas, A. Toxic Cyanobacteria Blooms in the Lithuanian Part of the Curonian Lagoon. Oceanologia 2009, 51, 203-216. [CrossRef]

13. Pilkaitytè, R.; Overlingè, D.; Gasiūnaitè, Z.R.; Mazur-Marzec, H. Spatial and Temporal Diversity of Cyanometabolites in the Eutrophic Curonian Lagoon (SE Baltic Sea). Water 2021, 13, 1760. [CrossRef]

14. Demay, J.; Bernard, C.; Reinhardt, A.; Marie, B. Natural Products from Cyanobacteria: Focus on Beneficial Activities. Mar. Drugs 2019, 17, 320. [CrossRef]

15. Nowruzi, B.; Sarvari, G.; Blanco, S. Applications of cyanobacteria in biomedicine. In Handbook of Algal Science, Technology and Medicine; Elsevier: Amsterdam, The Netherlands, 2020; pp. 441-453.

16. Swain, S.S.; Paidesetty, S.K.; Padhy, R.N. Antibacterial, Antifungal and Antimycobacterial Compounds from Cyanobacteria. Biomed. Pharmacother. 2017, 90, 760-776. [CrossRef]

17. Lauritano, C.; Martín, J.; de La Cruz, M.; Reyes, F.; Romano, G.; Ianora, A. First Identification of Marine Diatoms with AntiTuberculosis Activity. Sci. Rep. 2018, 8. [CrossRef]

18. Marrez, D.A.; Naguib, M.M.; Sultan, Y.Y.; Higazy, A.M. Antimicrobial and Anticancer Activities of Scenedesmus obliquus Metabolites. Heliyon 2019, 5, e01404. [CrossRef] [PubMed]

19. Kini, S.; Divyashree, M.; Mani, M.K.; Mamatha, B.S. Algae and cyanobacteria as a source of novel bioactive compounds for biomedical applications. In Advances in Cyanobacterial Biology; Elsevier: London, UK, 2020; pp. 173-194.

20. Baldisserotto, C.; Sabia, A.; Ferroni, L.; Pancaldi, S. Biological Aspects and Biotechnological Potential of Marine Diatoms in Relation to Different Light Regimens. World J. Microbiol. Biotechnol. 2019, 35. [CrossRef] [PubMed]

21. Singh, S.K.; Kaur, R.; Bansal, A.; Kapur, S.; Sundaram, S. Biotechnological exploitation of cyanobacteria and microalgae for bioactive compounds. In Biotechnological Production of Bioactive Compounds; Elsevier: Amsterdam, The Netherlands, 2019; pp. 221-259. ISBN 9780444643230.

22. Ventola, C.L. The Antibiotic Resistance Crisis: Causes and Threats. P T J. 2015, 40, 277-283.

23. Machowska, A.; Lundborg, C.S. Drivers of Irrational Use of Antibiotics in Europe. Int. J. Environ. Res. Public Health 2019, 16, 27. [CrossRef] [PubMed]

24. World Health Organisation. WHO Report on Cancer: Setting Priorities, Investing Wisely and Providing Care for All; WHO: Geneva, Switzerland, 2020.

25. Blunt, J.W.; Copp, B.R.; Keyzers, R.A.; Munro, M.H.G.; Prinsep, M.R. Marine Natural Products. Nat. Prod. Rep. 2015, 32, 116-211. [CrossRef] [PubMed]

26. Welker, M.; von Döhren, H. Cyanobacterial Peptides-Nature's Own Combinatorial Biosynthesis. FEMS Microbiol. Rev. 2006, 30, 530-563. [CrossRef] [PubMed]

27. Prarthana, J.; Maruthi, K.R. Fresh Water Algae as a Potential Source of Bioactive Compounds for Aquaculture and Significance of Solvent System in Extraction of Antimicrobials. Asian J. Sci. Res. 2018, 12, 18-28. [CrossRef]

28. Ingebrigtsen, R.A.; Hansen, E.; Andersen, J.H.; Eilertsen, H.C. Field Sampling Marine Plankton for Biodiscovery. Sci. Rep. 2017, 7. [CrossRef] [PubMed]

29. Utermöhl, H. Zur Vervollkommnung Der Quantitativen Phytoplankton-Methodik. Int. Ver. Theor. Angew. Limnol. Mitt. 1958, 9, 1-38. [CrossRef]

30. HELCOM. Manual of Marine Monitoring in the Combine Programme of HELCOM. Annex C-6: Guidelines Concerning Phytoplankton Species Composition, Abundance and Biomass. Available online: https://helcom.fi/media/publications/Manual-forMarine-Monitoring-in-the-COMBINE-Programme-of-HELCOM.pdf (accessed on 11 June 2021). 
31. Olenina, I.; Hajdu, S.; Edler, L.; Andersson, A.; Wasmund, N.; Busch, S.; Göbel, J.; Gromisz, S.; Huseby, S.; Huttunen, M.; et al. Biovolumes and Size-Classes of Phytoplankton in the Baltic Sea Helsinki Commission Baltic Marine Environment Protection Commission; HELCOM: Helsinki, Finland, 2006; Volume 106.

32. Starmach, K. Dinophyceae—Dinofity. Raphidophyceae—Rafidofity. In Flora slodkowodna Polski 5; Starmach, K., Sieminska, J., Eds.; PWN: Warszawa, Krakow, 1974.

33. Tikkanen, T.; Willen, T. Vaxtplanktonflora; Statens Naturvardsverk: Solna, Sweden, 1992.

34. Komárek, J.; Anganostidis, K. Cyanoprokaryota. In Süßwasserflora von Mitteleuropa; Büdel, B., Gärtner, G., Krienitz, L., Schagerl, M., Eds.; Elsevier: München, Germany, 2008; Volume 19/1.

35. Komárek, J. Cyanoprokaryota: 3rd Part: Heterocystous Genera. In Süßwasserflora von Mitteleuropa; Büdel, B., Gärtner, G., Krienitz, L., Schagerl, M., Eds.; Springer Spektrum: Berlin/Heidelberg, Germany, 2013.

36. Kotlarska, E.; Łuczkiewicz, A.; Burzyński, A. Vibrio cholerae in the Polish Coastal Waters of the Baltic Sea-Single Case or a Sign of Climate Warming? Acta Biochim. Pol. 2018, 65, 69.

37. Kotlarska, E.; Łuczkiewicz, A.; Baraniak, A.; Jankowska, K.; Całkiewicz, J. ESBL-Producing Aeromonas spp. Isolated from Wastewater and Marine Environment. Acta Biochim. Pol. 2018, 65.

38. Sadowy, E.; Luczkiewicz, A. Drug-Resistant and Hospital-Associated Enterococcus Faecium from Wastewater, Riverine Estuary and Anthropogenically Impacted Marine Catchment Basin. BMC Microbiol. 2014, 14. [CrossRef] [PubMed]

39. Felczykowska, A.; Pawlik, A.; Mazur-Marzec, H.; Torunska-Sitarz, A.; Narajczyk, M.; Richert, M.; Wegrzyn, G.; HermanAntosiewicz, A. Selective Inhibition of Cancer Cells' Proliferation by Compounds Included in Extracts from Baltic Sea Cyanobacteria. Toxicon 2015, 108, 1-10. [CrossRef]

40. Pluotno, A.; Carmeli, S. Banyasin A and Banyasides A and B, Three Novel Modified Peptides from a Water Bloom of the Cyanobacterium Nostoc sp. Tetrahedron 2005, 61, 575-583. [CrossRef]

41. Ocampo Bennet, X. Peptide Au Seiner Cyanobakterien Wasserblütte (1998) Aus Dem Wannsee/Berli: Strukturen and Biologische Wirksamkeit; University of Freiburg: Breisgau, Germany, 2007.

42. Mazur-Marzec, H.; Błaszczyk, A.; Felczykowska, A.; Hohlfeld, N.; Kobos, J.; Toruńska-Sitarz, A.; Devi, P.; Montalvão, S.; D’souza, L.; Tammela, P.; et al. Baltic Cyanobacteria-A Source of Biologically Active Compounds. Eur. J. Phycol. 2015, 50, 343-360. [CrossRef]

43. Jaccard, P. Étude Comparative de La Distribution Florale Dans Une Portion Des Alpes et Du Jura. Bull. Soc. Vaud. Sci. Nat. 1901, 37, 547-579. [CrossRef]

44. Schlee, D.; Sneath, P.H.A.; Sokal, R.R.; Freeman, W.H. Numerical Taxonomy. The Principles and Practice of Numerical Classification. Syst. Zool. 1975, 24, 263. [CrossRef]

45. Fujii, K.; Mayumi, T.; Noguchi, K.; Kashiwagi, T.; Akashi, S.; Sivonen, K.; Hirayama, K.; Harada, K. Mass Spectrometric Studies of Peptides from Cyanobacteria under FAB MS/MS Conditions. J. Mass Spectrom. Soc. Jpn. 2000, 48, 56-64. [CrossRef]

46. Welker, M.; Brunke, M.; Preussel, K.; Lippert, I.; von Döhren, H. Diversity and Distribution of Microcystis (Cyanobacteria) Oligopeptide Chemotypes from Natural Communities Studies by Single-Colony Mass Spectrometry. Microbiology 2004, 150, 1785-1796. [CrossRef]

47. Czarnecki, O.; Henning, M.; Lippert, I.; Welker, M. Identification of Peptide Metabolites of Microcystis (Cyanobacteria) That Inhibit Trypsin-like Activity in Planktonic Herbivorous Daphnia (Cladocera). Environ. Microbiol. 2006, 8, 77-87. [CrossRef] [PubMed]

48. Miles, C.O.; Melanson, J.E.; Ballot, A. Sulfide Oxidations for LC-MS Analysis of Methionine-Containing Microcystins in Dolichospermum flos-Aquae NIVA-CYA 656. Environ. Sci. Technol. 2014, 48, 13307-13315. [CrossRef]

49. Bortoli, S.; Volmer, D.A. Characterization and Identification of Microcystins by Mass Spectrometry. Eur. J. Mass Spectrom. 2014, 20, 1-19. [CrossRef] [PubMed]

50. Puddick, J.; Prinsep, M.R.; Wood, S.A.; Kaufononga, S.A.F.; Cary, S.C.; Hamilton, D.P. High Levels of Structural Diversity Observed in Microcystins from Microcystis CAWBG11 and Characterization of Six New Microcystin Congeners. Mar. Drugs 2014, 12, 5372-5395. [CrossRef]

51. Bouaïcha, N.; Miles, C.O.; Beach, D.G.; Labidi, Z.; Djabri, A.; Yasmine Benayache, N.; Nguyen-Quang, T.; Chadli Bendjedid, U.; Taref, E. Structural Diversity, Characterization and Toxicology 2 of Microcystins 3. Toxins 2019, 11, 714. [CrossRef]

52. Jones, M.R.; Pinto, E.; Torres, M.A.; Dörr, F.; Mazur-Marzec, H.; Szubert, K.; Tartaglione, L.; Dell'Aversano, C.; Miles, C.O.; Beach, D.G.; et al. CyanoMetDB, a Comprehensive Public Database of Secondary Metabolites from Cyanobacteria. Water Res. 2021, 196. [CrossRef] [PubMed]

53. Zervou, S.K.; Gkelis, S.; Kaloudis, T.; Hiskia, A.; Mazur-Marzec, H. New Microginins from Cyanobacteria of Greek Freshwaters. Chemosphere 2020, 248. [CrossRef] [PubMed]

54. Carneiro, R.L.; Dörr, F.A.; Dörr, F.; Bortoli, S.; Delherbe, N.; Vásquez, M.; Pinto, E. Co-Occurrence of Microcystin and Microginin Congeners in Brazilian Strains of Microcystis sp. FEMS Microbiol. Ecol. 2012, 82, 692-702. [CrossRef]

55. Erhard, M.; von Döhren, H.; Jungblut, P. Rapid Typing and Elucidation of New Secondary Metabolites of Intact Cyanobacteria Using MALDI-TOF Mass Spectrometry. Nat. Biotechnol. 1999, 15, 906-909. [CrossRef] [PubMed]

56. Spoof, L.; Błaszczyk, A.; Meriluoto, J.; Cegłowska, M.; Mazur-Marzec, H. Structures and Activity of New Anabaenopeptins Produced by Baltic Sea Cyanobacteria. Mar. Drugs 2016, 14, 8. [CrossRef] 
57. Nishizawa, A.; bin Arshad, A.; Nishizawa, T.; Asayama, M.; Fujii, K.; Nakano, T.; Harada, K.I.; Shirai, M. Cloning and Characterization of a New Hetero-Gene Cluster of Nonribosomal Peptide Synthetase and Polyketide Synthase from the Cyanobacterium Microcystis aeruginosa K-139. J. Gen. Appl. Microbiol. 2007, 53, 17-27. [CrossRef]

58. Janssen, E.M.L. Cyanobacterial Peptides beyond Microcystins-A Review on Co-Occurrence, Toxicity, and Challenges for Risk Assessment. Water Res. 2019, 151, 488-499. [CrossRef] [PubMed]

59. Kurmayer, R.; Deng, L.; Entfellner, E. Role of Toxic and Bioactive Secondary Metabolites in Colonization and Bloom Formation by Filamentous Cyanobacteria Planktothrix. Harmful Algae 2016, 54, 69-86. [CrossRef]

60. Shishido, T.K.; Popin, R.V.; Jokela, J.; Wahlsten, M.; Fiore, M.F.; Fewer, D.P.; Herfindal, L.; Sivonen, K. Dereplication of Natural Products with Antimicrobial and Anticancer Activity from Brazilian Cyanobacteria. Toxins 2019, 12, 12. [CrossRef] [PubMed]

61. Lürling, M. Grazing Resistance in Phytoplankton. Hydrobiologia 2021, 848, 237-249. [CrossRef]

62. Herrera, N.; Palacio, J.; Echeverri, F.; Ferrão-Filho, A. Effects of a Cyanobacterial Bloom Sample Containing Microcystin-LR on the Ecophysiology of Daphnia similis. Toxicol. Rep. 2014, 1, 909-914. [CrossRef]

63. Pawlik-Skowrońska, B.; Toporowska, M.; Mazur-Marzec, H. Effects of Secondary Metabolites Produced by Different Cyanobacterial Populations on the Freshwater Zooplankters Brachionus calyciflorus and Daphnia pulex. Environ. Sci. Pollut. Res. 2019, 26, 11793-11804. [CrossRef] [PubMed]

64. Ger, K.A.; Hansson, L.A.; Lürling, M. Understanding Cyanobacteria-Zooplankton Interactions in a More Eutrophic World. Freshw. Biol. 2014, 59, 1783-1798. [CrossRef]

65. Falaise, C.; François, C.; Travers, M.A.; Morga, B.; Haure, J.; Tremblay, R.; Turcotte, F.; Pasetto, P.; Gastineau, R.; Hardivillier, Y.; et al. Antimicrobial Compounds from Eukaryotic Microalgae against Human Pathogens and Diseases in Aquaculture. Mar. Drugs 2016, 14, 159. [CrossRef]

66. Takemura, A.F.; Chien, D.M.; Polz, M.F. Associations and Dynamics of Vibrionaceae in the Environment, from the Genus to the Population Level. Front. Microbiol. 2014, 5. [CrossRef] [PubMed]

67. Kim, H.-J.; Ryu, J.-O.; Lee, S.-Y.; Kim, E.-S.; Kim, H.-Y. Multiplex PCR for Detection of the Vibrio Genus and Five Pathogenic Vibrio Species with Primer Sets Designed Using Comparative Genomics. BMC Microbiol. 2015, 15, 239. [CrossRef] [PubMed]

68. Environmental Protection Agency US. Climate Change Indicators: Sea Surface Temperature. Climate Change Indicators in the United States. US EPA. Available online: https://www.epa.gov/climate-indicators/climate-change-indicators-sea-surfacetemperature (accessed on 14 June 2021).

69. Savadova-Ratkus, K.; Mazur-Marzec, H.; Karosienè, J.; Kasperovičienè, J.; Paškauskas, R.; Vitonytė, I.; Koreivienė, J. Interplay of Nutrients, Temperature, and Competition of Native and Alien Cyanobacteria Species Growth and Cyanotoxin Production in Temperate Lakes. Toxins 2021, 13, 23. [CrossRef] [PubMed]

70. Paerl, H.W.; Havens, K.E.; Hall, N.S.; Otten, T.G.; Zhu, M.; Xu, H.; Zhu, G.; Qin, B. Mitigating a Global Expansion of Toxic Cyanobacterial Blooms: Confounding Effects and Challenges Posed by Climate Change. Mar. Freshw. Res. 2020, 71, 579-592. [CrossRef]

71. Gyraite, G.; Katarzyte, M.; Schernewski, G. First Findings of Potentially Human Pathogenic Bacteria Vibrio in the South-Eastern Baltic Sea Coastal and Transitional Bathing Waters. Mar. Pollut. Bull. 2019, 149. [CrossRef] [PubMed]

72. Mouriño-Pérez, R.R.; Worden, R.Z.; Azam, F. Growth of Vibrio cholerae O1 in Red Tide Waters off California. Appl. Environ. Microbiol. 2003, 69, 6923-6931. [CrossRef] [PubMed]

73. Eiler, A.; Gonzalez-Rey, C.; Allen, S.; Bertilsson, S. Growth Response of Vibrio cholerae and Other Vibrio spp. to Cyanobacterial Dissolved Organic Matter and Temperature in Brackish Water. FEMS Microbiol. Ecol. 2007, 60, 411-418. [CrossRef] [PubMed]

74. World Health Organisation. Guidelines for Safe Recreational Water Environments. Volume 1, Coastal and Fresh Waters; WHO: Geneva, Switzerland, 2003; Volume 1.

75. Gheda, S.F.; Ismail, G.A. Natural Products from Some Soil Cyanobacterial Extracts with Potent Antimicrobial, Antioxidant and Cytotoxic Activities. An. Acad. Bras. De Cienc. 2020, 92, 1-18. [CrossRef] [PubMed]

76. Emparan, Q.; Harun, R.; Danquah, M.K. Role of Phycoremediation for Nutrient Removal from Wastewaters: A Review. Appl. Ecol. Environ. Res. 2019, 17, 889-915. [CrossRef]

77. Dar, R.A.; Sharma, N.; Kaur, K.; Phutela, U.G. Feasibility of Microalgal Technologies in Pathogen Removal from Wastewater. In Application of Microalgae in Wastewater Treatment; Springer International Publishing: Cham, Switzerland, 2019; pp. $237-268$.

78. Da Silva, M.F.; Tiago, I.; Veríssimo, A.; Boaventura, R.A.; Nunes, O.C.; Manaia, C.M. Antibiotic Resistance of Enterococci and Related Bacteria in an Urban Wastewater Treatment Plant. FEMS Microbiol. Ecol. 2006, 55, 322-329. [CrossRef]

79. Zahra, Z.; Choo, D.H.; Lee, H.; Parveen, A. Cyanobacteria: Review of Current Potentials and Applications. Environments 2020, 7, 13. [CrossRef]

80. Rico, M.; González, A.G.; Santana-Casiano, M.; González-Dávila, M.; Pérez-Almeida, N.; Tangil, M.S. de Production of Primary and Secondary Metabolites Using Algae. In Prospects and Challenges in Algal Biotechnology; Springer: Singapore, 2017; pp. 311-326.

81. Silva-Stenico, M.E.; Silva, C.S.P.; Lorenzi, A.S.; Shishido, T.K.; Etchegaray, A.; Lira, S.P.; Moraes, L.A.B.; Fiore, M.F. Non-Ribosomal Peptides Produced by Brazilian Cyanobacterial Isolates with Antimicrobial Activity. Microbiol. Res. 2011, 166, 161-175. [CrossRef]

82. Rojas, V.; Rivas, L.; Cárdenas, C.; Guzmán, F. Cyanobacteria and Eukaryotic Microalgae as Emerging Sources of Antibacterial Peptides. Molecules 2020, 25, 5804. [CrossRef]

83. Skočibušić, M.; Lacić, S.; Rašić, Z. Evaluation of Antimicrobial Potential of the Marine Cyanobacterium, Rivularia mesenterica. J. Adv. Microbiol. 2019, 16, 1-11. [CrossRef] 
84. Tan, L.T.; Phyo, M.Y. Marine Cyanobacteria: A Source of Lead Compounds and Their Clinically-Relevant Molecular Targets. Molecules 2020, 25, 2197. [CrossRef]

85. Chlipala, G.E.; Mo, S.; Orjala, J. Chemodiversity in Freshwater and Terrestrial Cyanobacteria-A Source for Drug Discovery. Curr. Drug Targets 2011, 12, 1654-1673. [CrossRef] [PubMed]

86. Mazur-Marzec, H.; Fidor, A.; Cegłowska, M.; Wieczerzak, E.; Kropidłowska, M.; Goua, M.; Macaskill, J.; Edwards, C. Cyanopeptolins with Trypsin and Chymotrypsin Inhibitory Activity from the Cyanobacterium Nostoc edaphicum CCNP1411. Mar. Drugs 2018, 16, 220. [CrossRef]

87. Weckesser, J.; Martin, C.; Jakobi, C. Cyanopeptolins, Depsipeptides from Cyanobacteria. Syst. Appl. Microbiol. 1996, 19, 133-138. [CrossRef]

88. Tsukamoto, S.; Painuly, P.; Young, K.A.; Yang, X.; Shimizu, Y.; Cornell, L. Microcystilide A: A Novel Cell-Differentiation-Promoting Depsipeptide from Microcystis aeruginosa NO-15-1840. J. Am. Chem. Soc. 1993, 115, 11046-11047. [CrossRef]

89. Salem, O.M.; el Assi, R.K. Bioactive Constituents of Three Algal Species Extracts and Their Anticancer Activity against Human Cancer Cell Lines. Egypt. J. Phycol. 2020, 21, 2020.

90. Ujvárosi, A.Z.; Hercog, K.; Riba, M.; Gonda, S.; Filipič, M.; Vasas, G.; Žegura, B. The Cyanobacterial Oligopeptides Microginins Induce DNA Damage in the Human Hepatocellular Carcinoma (HepG2) Cell Line. Chemosphere 2020, 240. [CrossRef] [PubMed]

91. Okino, T.; Murakami, M.; Ryo, H.; Hideaki, M.; Matsuda, H.; Yamaguchi, K. Micropeptins A and B, Plasmin and Trypsin Inhibitors from the Blue-Green Alga Microcystis aeruginosa. Tetrahedron Lett. 1993, 34, 8131-8134. [CrossRef]

92. Bober, B.; Bialczyk, J. Determination of the Toxicity of the Freshwater Cyanobacterium Woronichinia naegeliana (Unger) Elenkin. J. Appl. Phycol. 2017, 29, 1355-1362. [CrossRef] [PubMed]

93. Ishida, K.; Kato, T.; Murakami, M.; Watanabe, M.; Watanabe, M.F. Microginins, Zinc Metalloproteases Inhibitors Cyanobacterium Microcystis aeruginosa. Tetrahedron 2000, 56, 8643-8656. [CrossRef]

94. Barkia, I.; Al-Haj, L.; Hamid, A.A.; Zakaria, M.; Saari, N.; Zadjali, F. Indigenous Marine Diatoms as Novel Sources of Bioactive Peptides with Antihypertensive and Antioxidant Properties. Int. J. Food Sci. Technol. 2019, 54, 1514-1522. [CrossRef]

95. Hielscher-Michael, S.; Griehl, C.; Buchholz, M.; Demuth, H.-U.; Arnold, N.; Wessjohann, L.A. Natural Products from Microalgae with Potential against Alzheimer's Disease: Sulfolipids Are Potent Glutaminyl Cyclase Inhibitors. Mar. Drugs 2016, 14, 203. [CrossRef] [PubMed]

96. Kusaikin, M.I.; Ermakova, S.P.; Shevchenko, N.M.; Isakov, V.V.; Gorshkov, A.G.; Vereshchagin, A.L.; Grachev, M.A.; Zvyagintseva, T.N. Structural Characteristics and Antitumor Activity of a New Chrysolaminaran from the Diatom Alga Synedra acus. Chem. Nat. Compd. 2010, 46, 1-4. [CrossRef]

97. Prestegard, S.K.; Oftedal, L.; Coyne, R.T.; Nygaard, G.; Skjærven, K.H.; Knutsen, G.; Døskeland, S.O.; Herfindal, L. Marine Benthic Diatoms Contain Compounds Able to Induce Leukemia Cell Death and Modulate Blood Platelet Activity. Mar. Drugs 2009, 7, 605. [CrossRef] [PubMed] 